\title{
Challenges associated with the behaviour of radioactive particles in the environment
}

Salbu, Brit; Kashparov, Valery; Lind, Ole Christian; Garcia-Tenorio, Rafael; Johansen, Mathew P.; Child, David P.; Roos, Per; Sancho, Carlos

Published in:

Journal of Environmental Radioactivity

Link to article, DOI:

10.1016/j.jenvrad.2017.09.001

Publication date:

2018

Document Version

Peer reviewed version

Link back to DTU Orbit

Citation (APA):

Salbu, B., Kashparov, V., Lind, O. C., Garcia-Tenorio, R., Johansen, M. P., Child, D. P., Roos, P., \& Sancho, C. (2018). Challenges associated with the behaviour of radioactive particles in the environment. Journal of Environmental Radioactivity, 186, 101-115. https://doi.org/10.1016/j.jenvrad.2017.09.001

\section{General rights}

Copyright and moral rights for the publications made accessible in the public portal are retained by the authors and/or other copyright owners and it is a condition of accessing publications that users recognise and abide by the legal requirements associated with these rights.

- Users may download and print one copy of any publication from the public portal for the purpose of private study or research.

- You may not further distribute the material or use it for any profit-making activity or commercial gain

- You may freely distribute the URL identifying the publication in the public portal 


\title{
Challenges associated with the behavior of radioactive particles in the environment
}

Brit Salbu$^{1}$, Valery Kashparov ${ }^{2,1}$, Ole Christian Lind ${ }^{1}$, Rafael Garcia-Tenorio ${ }^{3}$, Mathew P. Johansen $^{4}$, David P. Child ${ }^{4}$, Per Roos ${ }^{5}$, Carlos M. Sancho ${ }^{6}$ and Christelle Courbet ${ }^{7}$

${ }^{1}$ CERAD CoE Environmental Radioactivity/Department of Environmental Sciences, Norwegian University of Life Sciences (NMBU), 1432 Aas, Norway

${ }^{2}$ National University of Life and Environmental Sciences of Ukraine (NUBiP of Ukraine), Ukraine ${ }^{3}$ University of Seville (USEV), Spain

${ }^{4}$ Australian Nuclear Science and Technology Organization (ANSTO), Australia

${ }^{5}$ Technical University of Denmark (DTU), Denmark

${ }^{6}$ Centro de Investigaciones Energéticas, Medioambientales y Tecnológicas (CIEMAT), Spain

${ }^{7}$ Institut de Radioprotection et de Surete Nucleaire (IRSN), Fontenay-aux-Roses, France

Key words: Radioactive particles; nuclear sources, advanced technologies, particle leaching, uptake in organisms

\section{Highlights:}

- A series of sources have contributed to the release of radioactive particles to the environment.

- The source term determine the composition of particles, the release scenario influences particle properties such as size distribution, crystalline structure, oxidation state.

- Particle weathering and leaching depend on particle properties such as oxidation state of carrying matrix.

- Particle retention in soils and sediments delay the ecosystem transfer.

- Soils and sediments containing particles can act as a diffuse source of associated radionuclides in the future.

- Uptake of particles in organisms occur, and particles retained in tissues act as point sources.

\begin{abstract}
A series of different nuclear sources associated with the nuclear weapon and fuel cycles have contributed to the release of radioactive particles to the environment. Following nuclear weapon tests, safety tests, conventional destruction of weapons, reactor explosions and fires, a major fraction of released refractory radionuclides such as uranium (U) and plutonium (Pu)
\end{abstract}


were present as entities ranging from sub microns to fragments. Furthermore, radioactive particles and colloids have been released from reprocessing facilities and civil reactors, from radioactive waste dumped at sea, and from NORM sites. Thus, whenever refractory radionuclides are released to the environment following nuclear events, radioactive particles should be expected.

Results from many years of research have shown that particle characteristics such as elemental composition depend on the source, while characteristics such as particle size distribution, structure, and oxidation state influencing ecosystem transfer depend also on the release scenarios. When radioactive particles are deposited in the environment, weathering processes occur and associated radionuclides are subsequently mobilized, changing the apparent $\mathrm{K}_{\mathrm{d}}$. Thus, particles retained in soils or sediments are unevenly distributed, and dissolution of radionuclides from particles may be partial. For areas affected by particle contamination, the inventories can therefore be underestimated, and impact and risk assessments may suffer from unacceptable large uncertainties if radioactive particles are ignored. To integrate radioactive particles into environmental impact assessments, key challenges include the linking of particle characteristics to specific sources, to ecosystem transfer, and to uptake and retention in biological systems. To elucidate these issues, the EC-funded COMET and RATE projects and the IAEA Coordinated Research Program on particles have revisited selected contaminated sites and archive samples. This COMET position paper summarizes new knowledge on key sources that have contributed to particle releases, including particle characteristics based on advanced techniques, with emphasis on particle weathering processes as well as on heterogeneities in biological samples to evaluate potential uptake and retention of radioactive particles.

\section{Introduction}

According to a recent summary of lessons learned from the Chernobyl accident, "one of the areas being significantly advanced" since 1986 was the characterization and environmental behaviour of hot particles” (Beresford et al., 2016). Chernobyl particles were first observed in samples collected during deposition in April-May 1986; air filters from Sweden (Devell et al., 1986) and ultrafiltered rainwater from Norway (Salbu, 1988), about $2000 \mathrm{~km}$ away from the source. The first international conference focusing on "hot" particles organized in Regensburg in Germany 1988 demonstrated the fact that radioactive particles of different sizes and 
activities were observed in many countries in Europe. Thus, it was believed by many scientists that radioactive particles were "a peculiarity of the Chernobyl accident“ (Sandalls et al., 1993). However, radioactive particles were already observed during the early nuclear weapons tests (Crocker et al., 1966). Later, history has shown that a series of different nuclear sources associated with the nuclear weapon and fuel cycles have contributed to the release of radioactive particles to the environment. By revisiting nuclear sites and collecting new samples or by reanalysis of archive samples using advanced technology, the radioactive particle phenomenon has been further explored in the present paper.

Radioactive particles are defined as a localized aggregation of radioactive atoms that give rise to an inhomogeneous distribution of radionuclides significantly different from that of the matrix background (IAEA, 2011). In water, particles are defined as entities having diameters larger than $0.45 \mu \mathrm{m}$, i.e. entities that will settle in still water due to gravity. Radionuclide species within the size range $0.001 \mu \mathrm{m}-0.45 \mu \mathrm{m}$ are referred to as radioactive colloids, nanoparticles or pseudo-colloids. Species less than $0.001 \mu \mathrm{m}\left(10^{3} \mathrm{Da}\right.$, about $\left.1 \mathrm{~nm}\right)$ are referred to as low molecular mass (LMM) species, and are believed to be mobile and potentially bioavailable. For soils and sediments grain size analysis differentiates between categories of sand (62 - 2,000 $\mu \mathrm{m})$, silt (4 - $62 \mu \mathrm{m})$ and clays $(0.2-4 \mu \mathrm{m})$, and particles larger than $2 \mathrm{~mm}$ should be referred to as fragments. In air, radioactive particles are classified according to the aerodynamic diameters, where particles less than 7- $10 \mu \mathrm{m}$ are considered respiratory. Following a nuclear event, radionuclides released from a source can be present in different physico-chemical forms ranging from LMM species believed to be mobile and potentially bioavailable, to inert particles or fragments that can be retained in soils and sediments (Fig.1). 


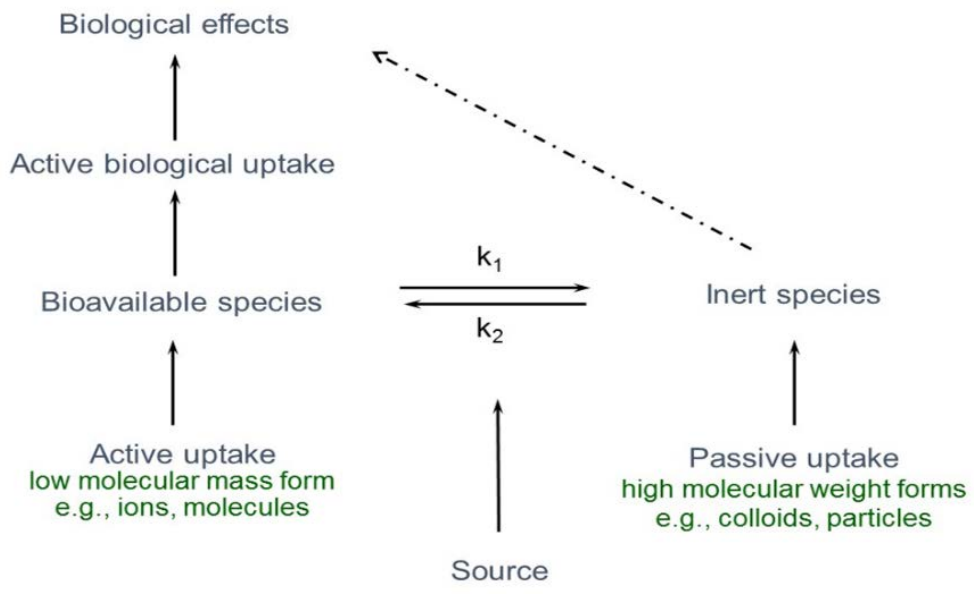

Figure 1. Radionuclides released from a source can be present in different physico-chemical forms ranging from low molecular mass (LMM) species believed to be mobile and potentially bioavailable, to inert particles that can be retained in soils and sediments. The system is dynamic and transformation processes such as particle weathering will influence the distribution of species over time (Salbu, 2000).

Information of radionuclide species released from a source as well as kinetics of the transformation processes are essential for assessing uptake, effects, impact and risks. The system is dynamic and due to interactions and transformation processes in the environment, particle growth mechanisms or dispersion processes will alter the original distribution of radionuclide species deposited. The fraction of LMM species can decrease due to interactions with soil components, while increases over time due to particle weathering.

Radioactive particles are formed due to critical (e.g., explosions, fires) or subcritical (e.g., corrosion processes) destruction of weapon and fuel matrices or other nuclear or radiological materials. At high temperature and pressure conditions such as nuclear weapon detonations, the particle composition depends on the weapon and construction materials, surroundings (e.g., infrastructure, geology) as well as the energy yield and the altitude of the blast. When the temperature of the fireball decreased, condensation processes took place and due to differences in volatility, chemical properties and half-lives, the particles were enriched with respect to refractory element and depleted with respect to volatiles. The resulting isotope/atom ratios of transuranic elements would reflect the particle emitting source. Similarly, in reactor accidents involving high temperature and high pressure release scenarios, solid materials can liquefy and volatiles escape, while refractory transuranics, fission and activation products remain when 
droplets are solidified. In contrast to hydrogen explosions, the presence of air during fire will influence the oxidation states and crystallographic structure of the carrying matrix. The composition of particles released during high temperature and pressure conditions (e.g., the Chernobyl reactor explosion) should therefore reflect burn-up and composition of refractory elements in the source, while the release conditions (e.g., the Chernobyl explosion or fire) are expected to influence the particle size distribution, crystallographic structures and oxidation states of relevance for ecosystem transfer of particle associated radionuclides.

Particles released during low temperature conditions are attributed to discharges from nuclear installations or to corrosion processes and damages of containment, being influenced by environmental conditions (e.g., water, $\mathrm{pH}$, redox, temperature). Particles and colloids released from nuclear installations as authorized discharges to the sea (e.g., Sellafield and La Hague reprocessing facilities) or to lakes (e.g., Mayak PA) will reflect the composition of the waste streams, representing the industrial processes. Due to corrosion, depleted uranium (DU) particles were released from DU ammunition penetrators buried in sand, ${ }^{60} \mathrm{Co}$ particles were released from waste containers dumped in the fjords of Novaya Zemlya, and U-Al particles were released from fuel misplaced in air cooled ducts at the Windscale pile during normal operations during the early 1950s (IAEA, 2011). Thus, the characteristics of particles released under low temperature conditions will be distinctly different from those released under high temperature- pressure conditions.

To assess environmental impact and risks associated with ecosystems contaminated with radioactive particles, links must be established between the source term and deposition, ecosystem transfer, biological uptake and effects in exposed organisms. Assessments are traditionally based on average bulk mass or surface activity concentrations of radionuclides in environmental compartments $\left(\mathrm{Bq} / \mathrm{kg}, \mathrm{Bq} / \mathrm{m}^{2}\right.$ or $\left.\mathrm{Bq} / \mathrm{L}\right)$. Localised heterogeneities such as particles will, however, be unevenly distributed, hence representative sampling can be questionable and dissolution of particles prior to measurements may be partial (IAEA, 2011). Thus, the inventories can be underestimated, ecosystem transfer wrongly described and impact and risk assessments may appear significantly biased if radioactive particles are ignored.

Although radioactive particles in the environment have been accepted as a phenomenon, information on the ecosystem behaviour of particles is scarce. To integrate radioactive particles into environmental impact assessments, key challenges include the linking of particle 
characteristics to specific sources and to ecosystem transfer, and linking particle characteristics to uptake and retention in biological systems of relevance for dose estimates. Within the frame of the EU-funded COMET (COordination and iMplementation of a pan-European instrumenT for Radioecology) and RATE (RAdioactive particle Transformation processes) projects and in collaboration with the IAEA CRP (Coordinated Research Project on Environmental Behaviour and Potential Biological Impact of Radioactive Particles) selected particle contaminated sites have been revisited, and new samples (e.g., Maralinga and Montebello sites in Australia, Palomares in Spain; Chernobyl in Ukraine) and archive samples (Thule, Greenland; NORM samples from Central Asia and Fen, Norway), have been analysed utilizing state - of - the - art analytical technologies for particle characterization and particle leaching experiments. Thus, this COMET position paper summarizes new knowledge on key sources that have contributed to particle releases, with emphasis on particle characteristics, weathering processes and retention of radioactive particle in organisms.

\section{Particle characterization and leaching techniques}

A series of analytical tools are available for identification, isolation, and characterization of radioactive particles (IAEA, 2011) as summarized in Table 1, while the investigation of particle weathering rates and leaching potential is still scarce._To identify particles in water (precipitation, rivers, ground water), ultrafiltration ( $\mathrm{nm}$ to $\mu \mathrm{m}$ range membranes) can be performed in the field or in the lab, while cascade impactors with membranes having different cut-off levels (nm to mm) are frequently used for separating particle in air (Burns et al., 1995). In contaminated areas, "hot spots" can be identified using portable detectors, while imaging techniques such as digital phosphor imaging (digital autoradiography) have proved most useful for locating radioactive particles in a sample. Using micromanipulators under microscope, single micrometer sized particles can be isolated and extracted for further analysis.

Table 1. Analytical tools available in radioactive particle research, modified from IAEA (2011).

\begin{tabular}{llc}
\hline Method & Information obtained & Comments \\
\hline
\end{tabular}

Identification

Size fractionation in water followed by Size distribution

radioanalytical techniques

Cascade impactor with aerosol filters Size distribution (AMAD)

followed by radioanalytical techniques 
Portable monitors in the field

Digital autoradiography

Real-time imaging techniques

Repeated sample splitting combined with $\gamma$-spectrometry

Repeated sample mixing combined with $\gamma$-spectrometry

\section{Isolation}

Repeated sample splitting in fractions combined w/ light microscope and GMtube, $\gamma$-spectrometry or autoradiography

Direct identification in SEMconfirmation by XRMA

FIB-SEM

\section{Characterisation}

Scanning electron microscopy with XRMA

Analytical TEM (transmission electron microscopy)/STEM with XRMA, electron diffraction, EELS, HAADF

Nano- and micro focused XRF

Confocal $\mu$-XRF

Nano- and micro focused XANES

Nano- and micro focused XRD

Nano- and micro focused tomography

EXAFS
Hot spot identification

Distribution of radioactivity

Easy and time saving Non-destructive

Distribution of radioactivity

Easy and time saving Non-destructive

Elevated activities in sub-samples Non-destructive indicate heterogeneities

Skewed frequency distribution of the Non-destructive counts indicate heterogeneities

Elevated activity in sub-samples indicate Non-destructive heterogeneities

High atomic number elements identified Non-destructive as bright areas in BEI-mode Micro-surgery or micromanipulation of particles

Size distribution, surface morphology, Non-destructive elemental composition and distribution

Size distribution of colloids. Element Often timecomposition, crystalline structure, consuming sample chemical bonding and Z-contrast imaging preparation

Thin sections prepared by ultra microtome

Elemental composition and 2D Non-destructive distribution (depth information)

Elemental composition and 3D Non-destructive distribution

Oxidation state (distribution)

Non-destructive

Synchrotron based

Crystallographic structures

Non-destructive

Spatial distribution of density, elements, Non-destructive ox. states

Laboratory based

(nano-CT) or synchrotron based

Structure of non-crystalline materials Synchrotron based 
Micro-focused PIXE

Nano-SIMS, SIMS

LA-ICP-MS, LAMMA

Leaching experiments

Isotope or atom ratios by MS techniques

(ICP-MS, AMS, RIMS, TIMS, SIMS)

$\gamma$-spectrometry and x-ray spectrometry

$\alpha$-, $\beta$-spectrometry
Elemental composition and distribution

Size distribution and isotope ratios

Elemental and isotopic composition

Solubility/weathering rates

Source identification of individual

particles (isotope ratios)

Activity concentrations, activity ratios

Source identification (activity ratios)
Semi-destructive

Semi-destructive

Semi-destructive

Gradual destructive.

Results depend on

extraction agent

Destructive

techniques

Non-destructive

Destructive

techniques

When located, isolated and extracted, several solid state speciation techniques can be utilized to characterise properties of single particles collected in the environment. Particle characterization by non-destructive techniques such as transmission electron microscopy (TEM) or environmental scanning electron microscopes (ESEM) prior to the use of synchrotron radiation (SR) X-ray techniques have proved most useful. Utilizing Backscattered Electron Imaging (BEI) mode in SEM, bright areas reflect the presence of high atomic number elements, while the composition and distribution of elements in the upper particle surface layer is attained using Energy dispersive X-ray analysis (EDX). Alternatively, semi-destructive techniques such as secondary ionization mass spectrometry (SIMS), nano-SIMS or proton (or particle) induced $\mathrm{x}$-ray emission ( $\mu$-PIXE) are utilized to obtain information on the distribution of elements below the particle surface (Lopez et al., 2007; Novikov et al., 2006; Ranebo et al., 2007).

Synchrotron radiation (SR) nanoscopic and microscopic X-ray techniques represent state-ofthe-art technologies; where SR fluorescence analysis ( $\mu$-XRF) provides information on 2dimensional or 3-dimensional ( $\mu$-tomography) elemental distribution within individual particles, and nano/micro-X-ray diffraction $(\mu-\mathrm{XRD})$ gives information on the 2D or 3D crystallographic structures of solid particles. Nano or micro X-ray absorption near edge structure spectrometry ( $\mu$-XANES) provides information on the oxidation state of matrix elements on nanometer or micrometer scales, respectively. The combination of synchrotron based $\mu$-XRF, $\mu$-XRD, $\mu$-XANES and 3D tomo XAS applied on one single radioactive particle was first presented in 2001 (Salbu et al., 2001b). Extended x-ray absorption fine structure analysis (EXAFS) could potentially provide information on the coordination number and the 
distance to neighbouring atoms, if detailed knowledge on all atoms imbedded in the particle is available (Conradson, 2000).

Following non-destructive solid-state speciation techniques, leaching experiments provide important data on particle characteristics and the links to solubility, particle weathering rates and remobilization potential for particle associated radionuclides (and metals). Usually, bulk samples (soils, sediments) have been subject to leaching, while leaching experiments of single particles are scarce. Leaching is made by single abiotic agents such as simulated stomach juice (0.16 M HCl) and simulated lung fluids (Sdraulig et al., 2008) or extracted sequentially using reagents of increasing displacement and dissolution power (Kennedy et al., 1997; Skipperud and Salbu, 2015). Alternatively, biotic leaching can be made utilizing biological fluids such as incubation with rumen liquids or particles can be given to animals as part of their feed.

Within the the EU-funded RATE project and in collaboration with the IAEA CRP a protocol has been established with the aim of identifying key parameters affecting properties of particles when exposed to a variety of different water qualities, temperatures and abiotic leaching agents (COMET, 2017). When leaching experiments on single radioactive particles are performed, the same procedure should also be applied on bulk samples from which the particle was isolated. This will aid the interpretation of results obtained on particle transformation processes for a larger number of different particles, including re-adsorption processes, and also link new data to literature data. In the protocol, isolated and well characterized radioactive particles or small bulk samples known to be contaminated with particles are transferred to centrifuge tubes and extracted with $20 \mathrm{ml}$ of the leaching medium for $2 \mathrm{~h}$ (representative of a residence time in the stomach), $24 \mathrm{~h}$ (transit times through the intestines) and $168 \mathrm{~h}$ (long term potential mobility of radionuclides). For each leachate, size fractionation should be performed (total, $<0.45 \mu \mathrm{m}$, $<3 \mathrm{kDa}$, LMM based on $10000 \mathrm{rpm}$ centrifugation; difference $<0.45 \mu \mathrm{m}$ - <3kDa yields colloidal fraction) to identify the speciation of the remobilized radionuclides (or metals).

Particles should be characterized prior to and, if possible, after leaching experiments by nondestructive techniques, by using as a minimum gamma spectrometry. Additional techniques such as x-ray spectrometry, dose rate measurements, electron microscopy, nano-tomography and SR based XRF/XANES/XRD may also be used. Biotic transformation experiments using in vitro rumen liquid extractions (incubated at $39^{\circ} \mathrm{C}$ for $24 \mathrm{~h}$ ) and subsequent separation of solids and liquids using $10000 \mathrm{rpm}$ centrifugation was also performed within the RATE 
project, similar to the work by Cook and co-workers (1995). Finally, fully dissolved particles and leachates should be subjected to $\alpha, \beta$ and/or mass spectrometry such as ICP-MS, RIMS, TIMS, and especially accelerator mass spectrometry (AMS) due to the high sensitivity. By also determining atom/isotopic ratios, specific particle characteristics can be linked to the releasing source.

\section{Key sources contributing to particle releases}

Radioactive particles containing refractory radionuclides such as $\mathrm{U}$ and $\mathrm{Pu}$ have been identified within nuclear weapon test sites, in areas affected by conventional destruction of nuclear weapons, in areas affected by fallout from nuclear reactor explosion or fires, in areas affected by authorised discharges and accidental releases from reprocessing plants, and in areas influenced by radioactive wastes dumped at sea (IAEA, 2011). In addition, NORM particles are present within $\mathrm{U}$ mining areas, in areas with $\mathrm{U}$ or Th containing minerals (e.g., alum shales) and areas affected by NORM industries such as the phosphate industry and oil and gas explorations. Thus, releases of radioactive particles have occurred more frequently than usually anticipated, and particles should be expected if the refractory radionuclides are released from a source in the future.

Although hot spots reflecting radioactive particles have been identified at most contaminated sites, information on particle characteristics and ecosystem behaviour is scarce. Therefore, participants within the COMET and RATE projects and the IAEA CRP have revisited particle contaminated sites or re-analysed archived samples, especially from the Maralinga and Montebello test sites in Australia, the accident sites at Palomares in Spain and Thule in Greenland, the Chernobyl $30 \mathrm{~km}$ exclusion zone as well as NORM sites, utilizing state - of the - art analytical technologies for particle characterization and particle leaching.

\section{Nuclear weapons tests}

The more than 2400 atmospheric, ground surface, underground and under water nuclear tests represent the key sources contributing to radioactive particles in the environment (UNSCEAR, 2000). In addition, safety test (non-nuclear destructions) of nuclear materials were performed at several test sites. Radioactive particles containing refractory radionuclides such as $\mathrm{U}$ and $\mathrm{Pu}$ have been identified following tests (IAEA, 2011) performed by USA (Marshall Island and Nevada Test Site), by former USSR (Semipalatinsk Nuclear Test Site), by France (Mururoa, 
French Polynesia), and by UK (Maralinga and Montebello sites, Australia). Spherical (7-22 $\mu \mathrm{m})$ radioactive particles were identified in Japan following nuclear tests in China 1964 (Mamuro et al., 1965).

US tests at Marshall Island and Nevada Test Site: During 1946-1958, US performed 23 nuclear weapon tests in the atmosphere and at ground surface at the Bikini and Enewetak atolls, Marshall Islands. Crocker et al. (1966) reported that particle characteristics such as size distribution, shape and color depended on devices and shot conditions, as also seen in the Nevada Test Site. Autoradiography of samples from ground-surface shots showed large spherical particles (0.5-1 mm), while Si-O-rich particles containing Pu found at Marshall Island (i.e., Fig-Quince zone, Runit Island, Enewetok Atoll) were attributed to the 1958 Quince safety trail (Hamilton et al., 2009). During 1951-1992, 86 atmospheric weapon tests (UNSCEAR, 2000) and 828 underground tests (Kersting et al., 1999) took also place in the Nevada Test Site, US. According to Kersting et al. (Kersting et al., 1999) the majority of the refractory radionuclides involved in underground nuclear tests were incorporated into melted glass forming the bottom of test cavities. Particle properties varied largely and included fused or partially fused particles and large agglomerates consisting of individual small particles differing in color, specific activity, density and magnetic properties.

Former USSR tests sites at Semipalatinsk, Kazakhstan, and Novaya Zemlya: A total of 456 nuclear weapon tests were conducted during 1949 - 1989 (IAEA, 1998) within the Semipalatinsk Test Site (STS), Kazakhstan. Spherical reddish brown or black radioactive particles with diameters up to $15 \mu \mathrm{m}$ from the STS tests have been identified in Japan (Mamuro et al., 1962; Mamuro et al., 1966). Similarly, tropospheric transport of fallout from detonations at STS to Norway have been observed from hot spots and Pu atom ratios in archived air filters and real time meteorological data (Wendel et al., 2013). Thus, long distance particle transport from STS to Europe during 1950-1960ies may have played a more important role than previously anticipated. Glass-like vitrified particles have been observed in soil samples from the Balapan (Lind, 2006), Degelen (Solodukhin, 2005) and Ground zero (Lind, 2006) sites, whereas soil particles with $\mathrm{U}$ and Pu co-existing in highly concentrated small grains (tens of $\mu \mathrm{m}$ in size) were found at the Tel'kem craters (Conway et al., 2009; Lind, 2006). Although 88 atmospheric, 39 underground and at least 3 underwater nuclear weapon tests took place at 
Novaya Zemlya, and hot spots are reported (AMAP, 1997; Smith et al., 2000), no information on particle characteristics is available.

French tests at Fangataufa and Mururoa atolls, French Polynesia: During 1966 - 1996, 193 nuclear tests, including 15 safety trials were conducted by French authorities. Relatively large (200 - $1000 \mu \mathrm{m})$ Pu-containing particles originated from five safety test trials performed at Colette, at the northern part of Mururoa, were reported by (Danesi et al., 2002), while a Pu inclusion $(\sim 100 \mu \mathrm{m})$ attached to coral matrix were reported by Eriksson and co-workers (2005). The activity levels of ${ }^{239} \mathrm{Pu}$ and ${ }^{241} \mathrm{Am}$ in the particles ranged from $5 \mathrm{kBq}$ to about $1 \mathrm{MBq}$ and 0.2 to $5.6 \mathrm{kBq}$, respectively, predominately present as particles larger than $250 \mu \mathrm{m}$. No information on particle characteristics is available from the French tests in Algeria.

British tests at Maralinga and Montebello sites, Australia: In total, 12 detonations were conducted during 1952-1957 at the former British nuclear test sites in Australia which included Maralinga, Emu Plains and the Montebello Islands. The tests were performed from $30 \mathrm{~m}$ towers, from airdrop, balloon, at ground surface, and aboard the decommissioned HMS Plym (Child and Hotchkis, 2013; MARTAC, 2003). In addition, hundreds of "safety" tests were performed, such as those at the Taranaki site where approximately $22 \mathrm{~kg}$ of $\mathrm{Pu}$ was dispersed in non-fission or partial-fission tests (MARTAC, 2003). Particles containing Pu, Am, U, Cs and other radionuclides appear to dominate the residual contamination at the former test sites. Autoradiography images on a composite soil sample taken from within a plume that extends for tens of kilometres from the Taranaki site (Fig. 2) suggest the presence of more than 3000 readily-identifiable particles per square meter at some locations. 

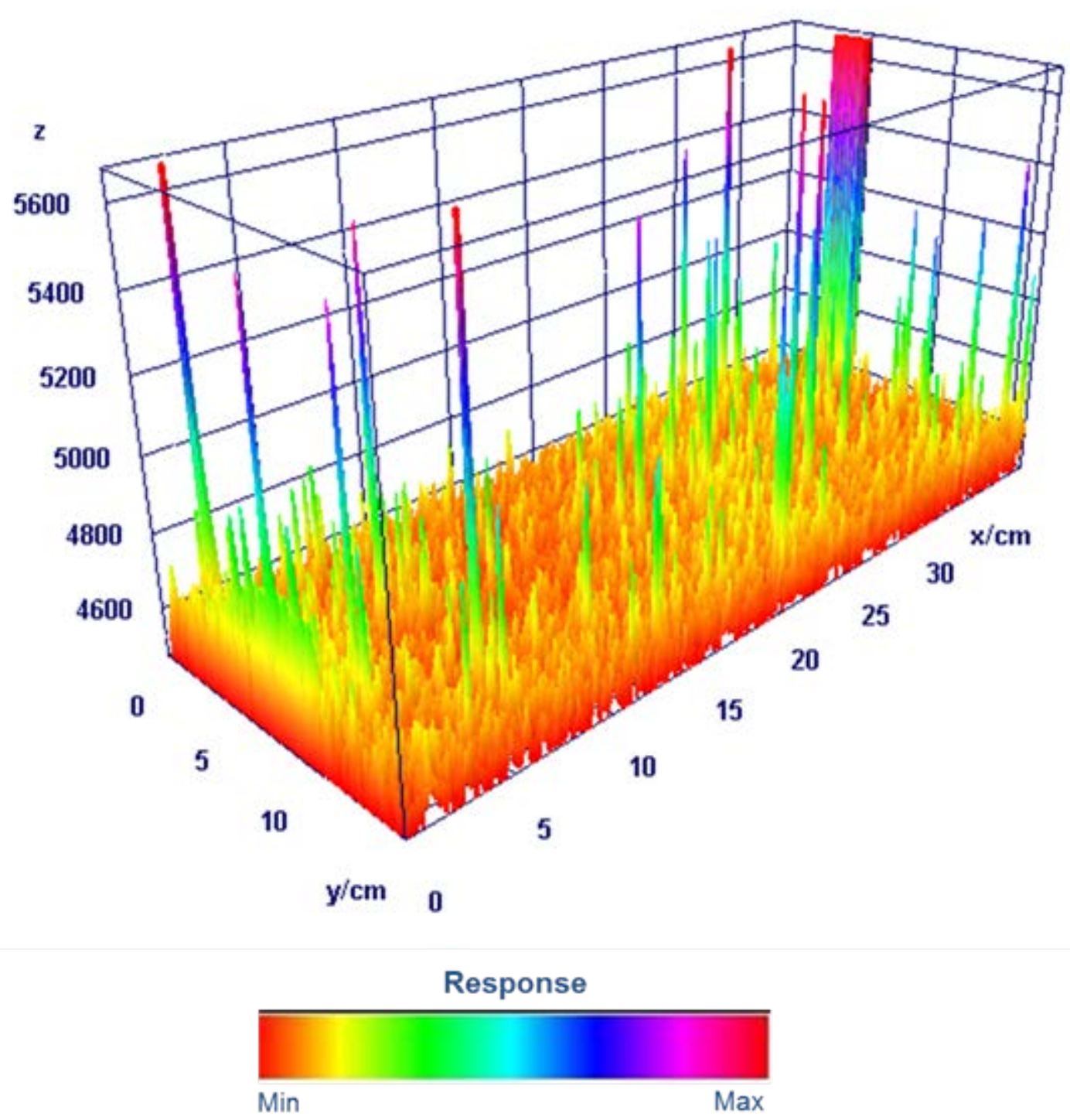

Figure 2. Image from photo-stimulated luminescence (PSL) autoradiography of a $5 \mathrm{~g}$ soil sample from the Taranaki, Maralinga site, spread thinly over an area of 40 x $20 \mathrm{~cm}$ (x and y axis). The $\mathrm{z}$ axis and measurement bar are of relative PSL intensity (energy deposited per unit area), and, while not calibrated to emission activity, are used here to visually demonstrate that the Am (and Pu) are predominantly contained within numerous small particles (COMET, 2017).

Within the particle structures, the location of the radionuclides relative to the surface is important for dose considerations and for radionuclide release during weathering. In one glassy fission fragment from a detonation test at Maralinga, the ${ }^{137} \mathrm{Cs}$ was clustered on the exterior, while ${ }^{90} \mathrm{Sr}$ occurred mainly in the interior of the same fragment. In contrast, Pu-dominated particles from the safety tests at Maralinga indicated an inhomogeneous core-shell structure (Fig 3), with the particle surface dominated by $\mathrm{Ca}$, Fe, and $\mathrm{U}$ thought to originate from the indigenous Maralinga soils. In this same particle, most of the $\mathrm{Pu}$ was in the interior, as 
determined by SR-XFM analyses and by nano-CT tomographic images (COMET, 2017). Plutonium in these particles was also determined to be present as an oxyhydroxide species by SR-XANES analyses (Ikeda-Ohno et al., 2016), similar to particles from Palomares and Thule. Understanding the structure of particles is important since the external surface interacts with the environment, or in the case of inhalation or ingestion, with lung or gastrointestinal tissues and fluids.
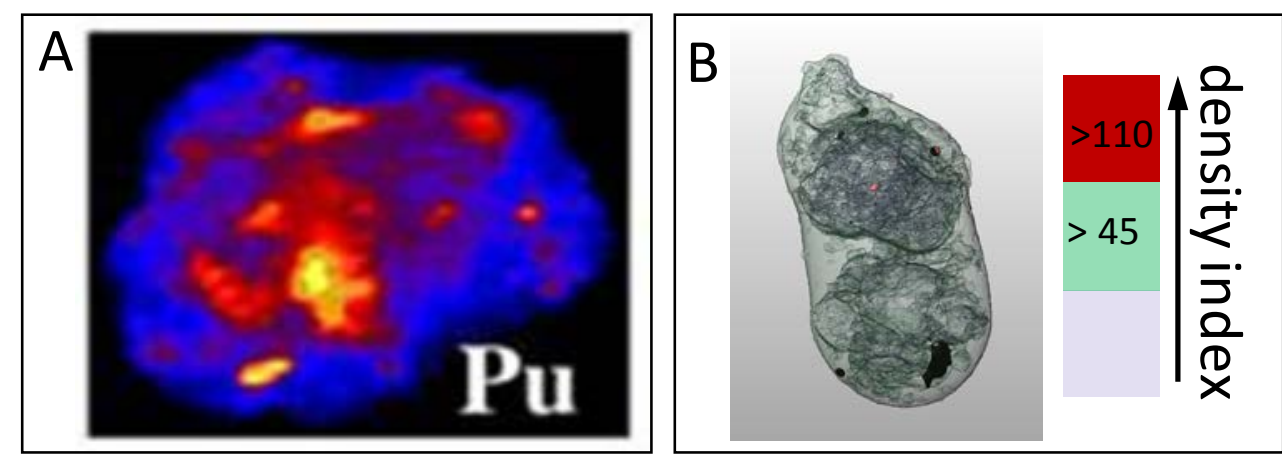

Figure 3. A: Synchrotron XFM 2-dimentional map of a particle from the non-nuclear testing at Taranaki, Maralinga, indicating most $\mathrm{Pu}$ is situated in the particle interior, while the exterior shell contains predominantly Ca, Fe, and U (COMET, 2017; Ikeda-Ohno et al., 2016). B: Transparent 3D rendering based on computerized nanotomography of a radioactive particle from Maralinga, showing high density regions expected to contain Pu and U (COMET, 2017).

Conventional destruction of nuclear weapon. Conventional nuclear weapon accidents have occurred at the McGuire air force base, New Jersey, at the Johnston Atoll, USA, at Palomares, Spain and at Thule air base, Greenland. In all cases, the fragmentation of the nuclear weapons resulted in Pu-U particle contamination. In contrast to the other sites, particles from Palomares and Thule have been well characterized.

The Palomares accident: On January 17, 1966, two U.S Air Force (USAF) airplanes; a B-52 bomber and a KC-135 tanker, collided during a refueling operation at 9,450 $\mathrm{m}$ over the southeastern coast of Spain. Both aircrafts were destroyed and 4 thermonuclear weapons fell to the ground in and around the Palomares village. Two of the weapons were recovered intact, while conventional explosion and subsequent fire of the remaining 2 weapons caused dispersion of plutonium-uranium particles over an area of about $2.30 \mathrm{~km}^{2}$, from the area of Puerto Blanco to the slopes of Sierra Almagrera. Fragments of bombs and aircrafts, as well as 
1,400 tons of contaminated soils and vegetation were transported to USA by sea, and deposited at Savannah River Facility in Aiken, USA in 1966.

The Thule accident: On January 21, 1968, the B-52G Stratofortress bomber 'HOBO 28' caught fire during a flight mission over North-East Greenland before crashing on the ice in North Star Bay about $12 \mathrm{~km}$ west of Thule Air Base. The conventional explosion resulted in dispersion of plutonium - uranium particles containing americium, contaminating marine and terrestrial environment. The Thule source term is dominated by a single source having a ${ }^{240} \mathrm{Pu} /{ }^{239} \mathrm{Pu}$ atomic ratio of 0.055 and a U/Pu atom ratio of about 1 (Eriksson et al., 2008). A second source with a ${ }^{240} \mathrm{Pu} /{ }^{239} \mathrm{Pu}$ atomic ratio of about 0.025 is present, but at a much lower abundance (Dahlgaard et al., 2001). The typical size distribution of particles at Thule points to a geometrical mean diameter of $2 \mu \mathrm{m}$, but the majority of the activity is held in relatively few large (10-1000 $\mu \mathrm{m})$ particles (Eriksson, 2002). The oxidation state of Pu and $\mathrm{U}$ in particles isolated from the marine sediments have been studied by Lind et.al. (2008; 2005; 2007) and Eriksson et.al. (2005), using $\mu$-XANES and transmission $\mu$-XRD (Fig. 4). The results indicated that $\mathrm{U}$ was predominantly present as uraninite $\left(\mathrm{UO}_{2}\right)$ with only a trace signal from oxidized uranium. Due to lack of plutonium standards for oxidation state determinations, $\mu$-XANES data are challenging to interpret, but the data allowed to exclude the presence of metallic $\mathrm{Pu}$ and $\mathrm{Pu}(\mathrm{VI})$. 

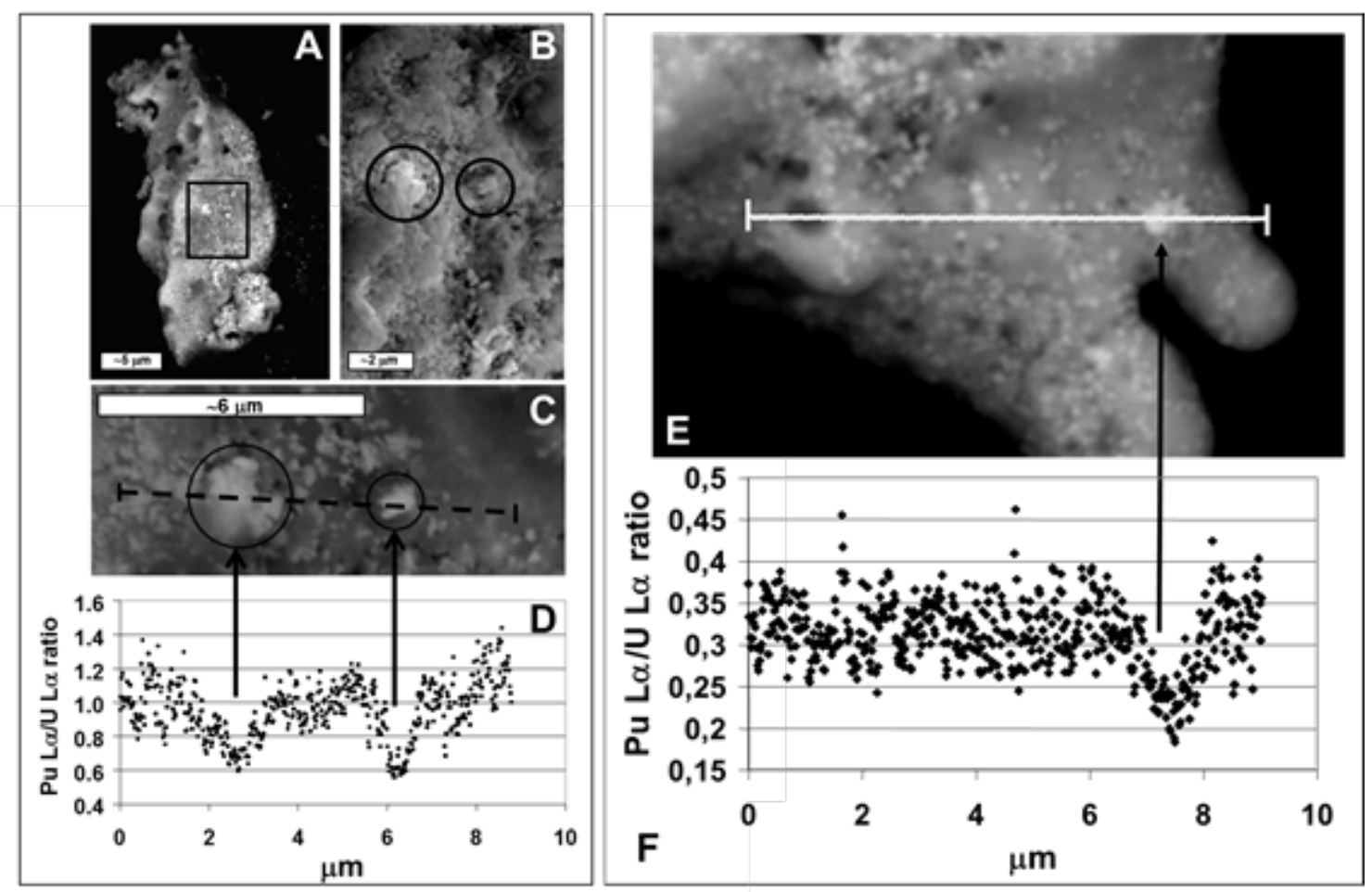

Figure 4. Comparison of a Palomares particle with a Thule particle based on ESEM line scan analysis (Lind et al., 2007). (A) BEI image of the whole Palomares particle shows high average atomic number area heterogeneities as brighter contrast. (B) SEI image shows the agglomerated structure of the spots highlighted in (A). (C) BEI image of the area analysed by line scan including the two bright spots in (B). (D) Pu $L \alpha / U$ L $\alpha$ intensity ratios along the line scan in $C$. (E) BEI image of the line scanned area of a Thule particle with varying Pu/U composition. (F) $\mathrm{Pu} L \alpha / \mathrm{U} L \alpha$ intensity ratios along a $\sim 9 \mu \mathrm{m}$ line scanned over the area indicated in (E).

Depleted uranium (DU) has frequently been used as ammunitions due to the density and hardness of the metal (e.g., the 1992 Golf war and the 1999 Balkan conflict). Following the impact with hard targets, DU is dispersed and ignited, and DU particles ranging from submicrons to several hundred micrometers, mostly in the respiratory fraction, have been observed in sand, soils and in damaged vehicles. Using SEM and synchrotron X-ray microscopic techniques, results showed that $\mathrm{U}$ in the impacted DU particles was oxidized to $\mathrm{UO}_{2}, \mathrm{U}_{3} \mathrm{O}_{8}$ or a mixture of these oxidation states. Following a fire in a DU ammunition storage facility, up to $\mathrm{mm}$ sized particles with $U$ present in oxidation state +5 and +6 , have been identified (Lind et al., 2009; Salbu et al., 2005). Although the source was similar (DU penetrators), the release scenario (detonation, fire) influenced the oxidation state of the released DU particles. 
Nuclear reactor accidents: During the years, a series of reactor accidents/events (e.g., Windscale, UK, 1958) have occurred and hot spots in the surroundings reflect the presence of particles (IAEA, 2011). In most cases, information of particle characteristics is limited, while Chernobyl particles and Fukushima particles have been investigated in more detail.

The Chernobyl Nuclear Power Plant (ChNPP) accident took place on April 26, 1986. As a consequence of the initial explosion, mechanical destruction of the $\mathrm{UO}_{2}$ fuel occurred under high pressure and high temperatures, and deposition of fuel particles took place to the West of the reactor. During the subsequent fire, volatile fission products and $U$ fuel particles were released under moderate temperatures and oxidising conditions (presence of air), and deposition of particles occurred to the North, Northeast and South of the plant (Kashparov et al., 1999). As a result, about 3-4 tons of $U$ fuel with variable burn-up were released into the atmosphere, either as fuel particles, as particles containing construction material or as condensation particles (Kashparov, 2003; Kashparov et al., 2003; Kuriny et al., 1993; Salbu et al., 2001b; Salbu et al., 1994). Radionuclides such as ${ }^{95} \mathrm{Zr},{ }^{95} \mathrm{Nb},{ }^{99} \mathrm{Mo},{ }^{141,144} \mathrm{Ce},{ }^{154,155} \mathrm{Eu}$, ${ }^{237,239} \mathrm{~Np},{ }^{238-242} \mathrm{Pu},{ }^{241,243} \mathrm{Am},{ }^{242,244} \mathrm{Cm}$ were released from the accidental unit only in the form of fuel particle matrix, while more than $90 \%$ of ${ }^{89,90} \mathrm{Sr},{ }^{103,106} \mathrm{Ru}$ and ${ }^{140} \mathrm{Ba}$ were also released as fuel particles.

Chernobyl fuel particles can be divided into 3 groups according to the particle properties (size, crystalline structure and oxidation state) and dissolution rates under natural conditions (Kashparov et al., 2004; Kashparov et al., 1999; Kashparov et al., 2000):

1. Chemically extra-stable U-Zr-O particles depleted in volatiles, formed as a result of hightemperature annealing of $\mathrm{UO}_{2}$ in the presence of zirconium in construction material, released during the initial explosion and deposited to the West of the reactor,

2. Non-oxidized chemically stable $\mathrm{UO}_{2}$ fuel particles released during the initial release (04/26/86), formed as a result of the mechanical destruction of nuclear fuel. These particles were also deposited along the narrow western trace of fallout. Leaching of the fission products from particles of this type during the accident was minimal. This fact is confirmed by a constant ratio of the fission products;

3. $\mathrm{UO}_{2+\mathrm{x}}$ particles of low chemical stability, formed as a result of oxidization of the nuclear fuel in the period 04/26/86 - 05/05/86. These particles were predominantly deposited to the North and South of the reactor. 
All three types of fuel particles was observed in the initial fallout (Fig. 5), and the relative contribution varied depending on the direction and distance from the ChNPP, on the degree of interaction with $\mathrm{Zr}$ and on the degree of oxidation. In addition, condensation particles containing volatiles were released.

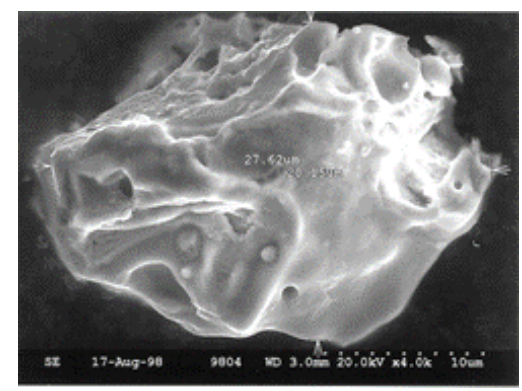

a
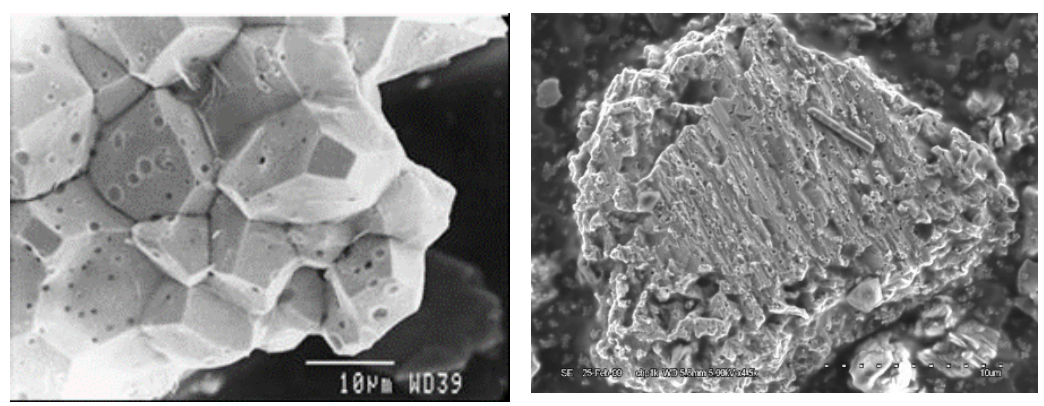

b

C

Figure 5. SEM images of fuel particles: (a) $\mathrm{ZrU}_{\mathrm{y}} \mathrm{O}_{\mathrm{x}}$ fuel particles; (b) $\mathrm{UO}_{2}$ fuel particles; (c) $\mathrm{UO}_{2+\mathrm{x}}$ fuel particles (Zhurba et al., 2009).

Fukushima particles: Shortly after the Fukushima Daiichi (FDNPP) accident in 2011, Miyamoto et al (2014) collected particles containing a series of short-lived gamma-emitters $\left({ }^{134} \mathrm{Cs},{ }^{136} \mathrm{Cs},{ }^{137} \mathrm{Cs},{ }^{129 \mathrm{~m}} \mathrm{Te},{ }^{140} \mathrm{Ba}\right.$ and $\left.{ }^{131} \mathrm{I}\right)$. Later, several authors have documented the presence of spherical 1-10 $\mu$ m sized particles containing ${ }^{137} \mathrm{Cs}$ as well as a series of stable refractory metals (Cs, Fe, Zn, U etc.), claiming that these particles originated from the FDNPP fuel (e.g., Abe et al., (2014)). If so, long-lived radioactive isotopes of the refractory metals should have been identified in these particles. It is therefore most probable that volatile radionuclides released as gases during the accidents have interacted with construction materials or have deposited on available surfaces such as fly ash, forming condensation particles during release or transport. To date, no spent fuel particles in the FDNPP surroundings have been identified, although measurements of the plutonium isotope ratios indicate that fuel particles have been released (Salbu and Lind, 2016).

Reprocessing plants: Particles have also been released via authorised discharges and accidental releases from reprocessing facilities. Among the 3 major reprocessing plants in Europe (Sellafield and Dounreay, UK, La Hague, France), Sellafield has been the major contributor of radionuclides to the north European seas (e.g., McCartney et al., 1994). Radionuclides have been discharged from Sellafield to the environment, as aerosols and particles in air emissions 
or as ions, colloids and particles via the effluent pipeline to the Irish Sea (Leonard et al., 1995; Salbu et al., 1993). Sediments in the Irish Sea, especially the mud patch outside the pipeline, act as a sink and particles are retained. Due to particle weathering, oxidation and TOC interactions, radionuclides such as $\mathrm{Pu}$ is remobilised and returned to the water phase. Due to previous discharges and accidents (IAEA, 2011), large and highly active (MBq) particles are observed annually at the beaches of Dounreay and Sellafield (Cresswell and Sanderson, 2012), and radioactive particles are also observed in the vicinity of reprocessing sites in Russia (Mayak PA, Krasnoyarsk-26, Tomsk-7).

NORM sources: Naturally occurring radionuclides may also occur as radioactive particles containing Th, $\mathrm{U}$ and daughter nuclides such as ${ }^{210} \mathrm{Po} /{ }^{210} \mathrm{~Pb}$, being heterogeneously distributed in minerals (Alsecz et al. 2007; Landa et al. 1994). Radioactive particles released from NORM (Naturally Occurring Radioactive Material) sites such as $U$ mining and tailing areas have almost been ignored (Alsecz et al., 2007; Boehnke et al., 2005; Landa et al., 1994; SelchauHansen et al., 1999) compared to particles carrying anthropogenic radionuclides. Lind and coworkers utilised micro-analytical techniques to identify radioactive particles (submicron to several hundred microns) and fragments containing $U$ and a range of heavy metals in dust samples, in mineral grains and mineral fragments from the abandoned Former Soviet Union U mining sites Kurday, Kazakhstan, Kadji Sai, Kyrgyzstan (Fig. 6) and Taboshar, Tajikistan . 


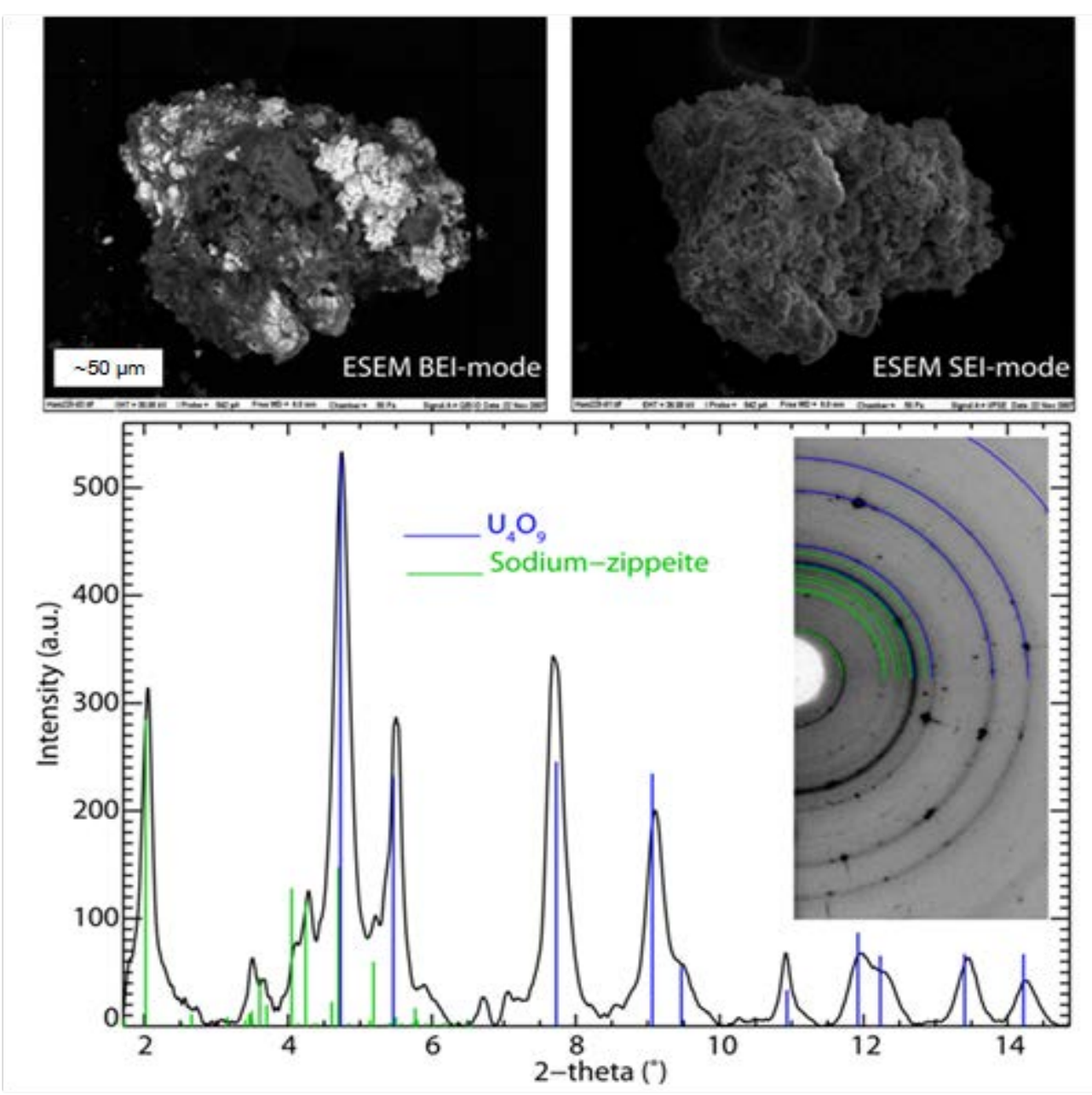

Figure 6. Electron microcopy (backscattered electron imaging mode; upper left and secondary electron imaging mode; upper right) of a NORM particle from the former Kadji Sai U mining site in Kyrgyzstan (Lind et al., 2013b). Diffractogram (bottom) obtained from the same particle shows that uraninite $\left(\mathrm{UO}_{2} / \mathrm{U}_{4} \mathrm{O}_{9}\right)$ coexists with Na-zippeite $\left(\mathrm{Na}_{4}\left(\mathrm{UO}_{2}\right)_{6}\left[(\mathrm{OH})_{10}\left(\mathrm{SO}_{4}\right)_{3}\right] \cdot 4 \mathrm{H}_{2} \mathrm{O}\right)$ within the particle. Darker pixels correspond to areas with a relatively higher concentration of the respective elements. Bar $50 \mu \mathrm{m}$.

Following the cold war, extensive $U$ mining and production took place at selected sites in Central Asia as a vital part of the nuclear weapon program in the former Soviet Union (Stegnar et al., 2011). The full industrial cycle of $U$ recovery and processing of $U$ ores have been undertaken in this region for about 50 years. Moreover, all types of $U$ recovery have been undertaken: open-cast extraction; underground mining; in situ leaching with sulphuric acid solutions. In addition, extensive mining for other metals have taken place in the same areas. In addition to extensive mining in Central Asia and East- Germany in the 1940ies, the Pridneprovsky Chemical Plant (PChP) was built in 1947 in Ukraine. By autoradiography using track detectors hundreds of $\alpha$-active particles per gram were observed, with size ranging 
between 2-20 $\mu \mathrm{m}$. The main risks associated with $\alpha$-active particles are assumed to be related to inhalation and ingestion pathways (COMET, 2017).

Similarly, particles enriched in Th and a series of metals as inclusions in rock fragments have also been observed in NORM samples from the thorium rich area Fen and Søve, Norway (Lind et al., 2011) situated in Telemark county, southern Norway. The concentrations of ${ }^{232} \mathrm{Th}$ in rødberg rocks and soils collected at locations within or near the Fen iron-mine ranged within 97 and $3000 \mathrm{mg} / \mathrm{kg}$. Extensive mining for Fe and $\mathrm{Nb}$ have been conducted within these areas, and waste from the mines also contain significant amounts of Th and $U$ as well as other metals. At all these sites, particles containing radionuclides and trace elements (lanthanoids, As, metals) have been demonstrated (Lind et al., 2013a; Popic et al., 2011).

\section{Linking particle characteristics to ecosystem transfer}

Soil and sediments can act as a sink for deposited particles, and particle contaminated soil and sediments may also act as a potential diffuse source in the future. Thus, knowledge with respect to particle characteristics and processes influencing particle weathering and remobilisation of associated radionuclides is needed to assess long-term impact from radioactive particle contamination. The ecosystem transfer of particle associated radionuclides will be delayed until particle weathering and remobilisation of associated radionuclides occur. The apparent soilwater distribution coefficient (Kd) can be extremely high (many orders of magnitude) if high activity particles are present in soils, and due to weathering the apparent $\mathrm{Kd}$ will change over time. Thus, the thermodynamic constant concept should be replaced with a rate function.

Since early 1960s leaching experiments have been performed based on small soil and sediment samples heavily contaminated with radioactive particles using simulated gastrointestinal tract fluids such as $0.16 \mathrm{M} \mathrm{HCl}$, simulated lung fluids or serum to link particle deposition to uptake in humans. Following the Marshall Island and Nevada nuclear weapons tests, spherical smallsized dense particles with high specific activity were formed due to high altitude nuclear weapon detonations (Crocker et al., 1966). Large irregularly shaped particles with lower density and specific activities, probably due to the interactions with soils, were produced due to ground surface shots. Leaching experiments using $0.16 \mathrm{M} \mathrm{HCl}$, mimicking stomach juice showed that the solubility of particle associated gamma- and beta emitting radionuclides 
depended on device and shot conditions, matrix composition, particle size and type. Particles originating from detonations at high altitudes were more inert than those from ground detonations. High water solubility is reported for $\mathrm{Pu}$ associated with algal crust of the Marshall Island atoll soils and debris from coral-surface detonations. The influence of environmental conditions is also illustrated for detonation particles from the semi-arid terrestrial site of Maralinga as contrasted with the marine-associated site at Montebello Islands (Fig. 7). The Montebello Island site is predominantly a highly calcareous and ferruginous sandstone area. The elevated Ca, Sr and Br content of the Montebello Island particles, especially on the particle surface, are likely attributable to a combination of the island geology, as well as close proximity of the site to the ocean (a source of $\mathrm{Br}$ ).
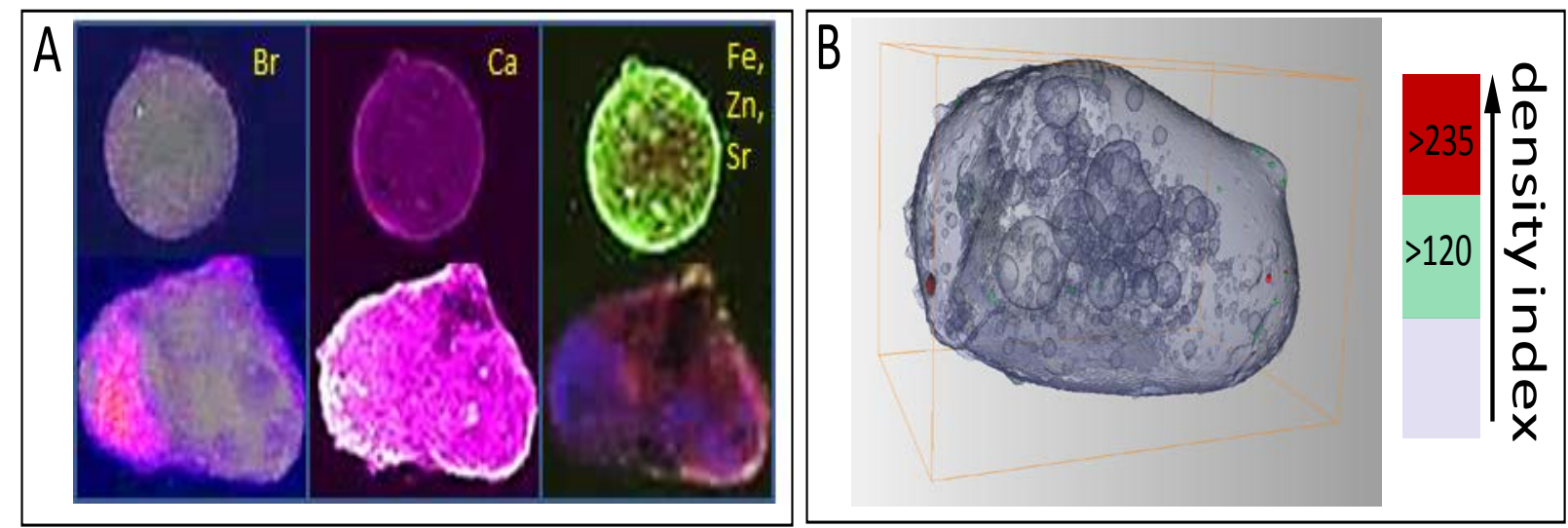

Figure 7. Characterization of radioactive particles from Australian nuclear tests. A: XRF elemental maps for two typical detonation particles from the semi-arid terrestrial site of Maralinga. Top row: spherical particle collected from Marcoo test site and from the marineassociated site at Montebello Islands. Bottom row: irregular aggregate from the Mosaic G2 test. The colour association of the rightmost image is red $=\mathrm{Fe}$, green $=\mathrm{Zn}$, blue $=\mathrm{Sr}$. $\mathrm{B}$ : Transparent 3D rendering based on computerized nanotomography of a Maralinga detonation particle showing high density inclusions as well as interior voids surrounded by glassy material (COMET, (2017).

Based on experimental work, small soil and sediment samples heavily contaminated with radioactive particles from a series of different sources have been leached $(0.16 \mathrm{M} \mathrm{HCl})$ to link information on site-specific particle characteristics of actinides originating from different source terms and release scenarios to potential bioavailability and extraction kinetics (Lind, 2006). The cumulative extracted fraction (\%) of ${ }^{241} \mathrm{Am}$ in soils collected in Semipalatinsk test site (Tel'kem 1, Tel'kem 2 and Lake Balapan) are shown in figure 8. The extraction of ${ }^{241} \mathrm{Am}$ from the soils was very low, with $72-85 \%$ of the ${ }^{241}$ Am remaining unextracted, even after 168 $\mathrm{h}$ of contact with the simulated stomach juices. The fraction (\%) of ${ }^{241} \mathrm{Am}$ dissolved at the end of these experiments were much lower than for those observed in contaminated Irish Sea 
sediments affected by releases from nuclear reprocessing at Sellafield (14 - $20 \%$ after 168 h). These results are consistent with reported plutonium sequential extraction data for samples collected in the same areas (Lucey et al., 2004). They confirm that a large proportion of the transuranics is associated with relatively mobile geochemical phases in sediments contaminated by releases from nuclear reprocessing at Sellafield, whereas most of the nuclear explosion derived transuranium contamination in Semipalatinsk is in a highly refractory, nonlabile form (Conway et al., 2009; Napoles et al., 2004). Experiments carried out on soil/sand samples from Kosovo and Kuwait known to be contaminated with DU particles showed that the solubility of $U$ from DU particles varied significantly depending on the release scenario, increasing with increasing oxidation state of U (Lind et al., 2009).

Comparing the potential bioavailability of actinides in particle contaminated Palomares soils and Thule sediments with the Semipalatinsk, Irish Sea and DU contaminated samples, results show that the nuclear weapon accident derived particles exhibit the lowest solubility in $0.16 \mathrm{M}$ $\mathrm{HCl}$. The particle weathering varies widely (Palomares 4 - $11.6 \%$, Thule 17 - $35 \%$ ) due to the heterogeneous nature of the actinide contamination, and the Thule sediment particles appears to be much more leachable than those in Palomares soils (COMET, 2017). 


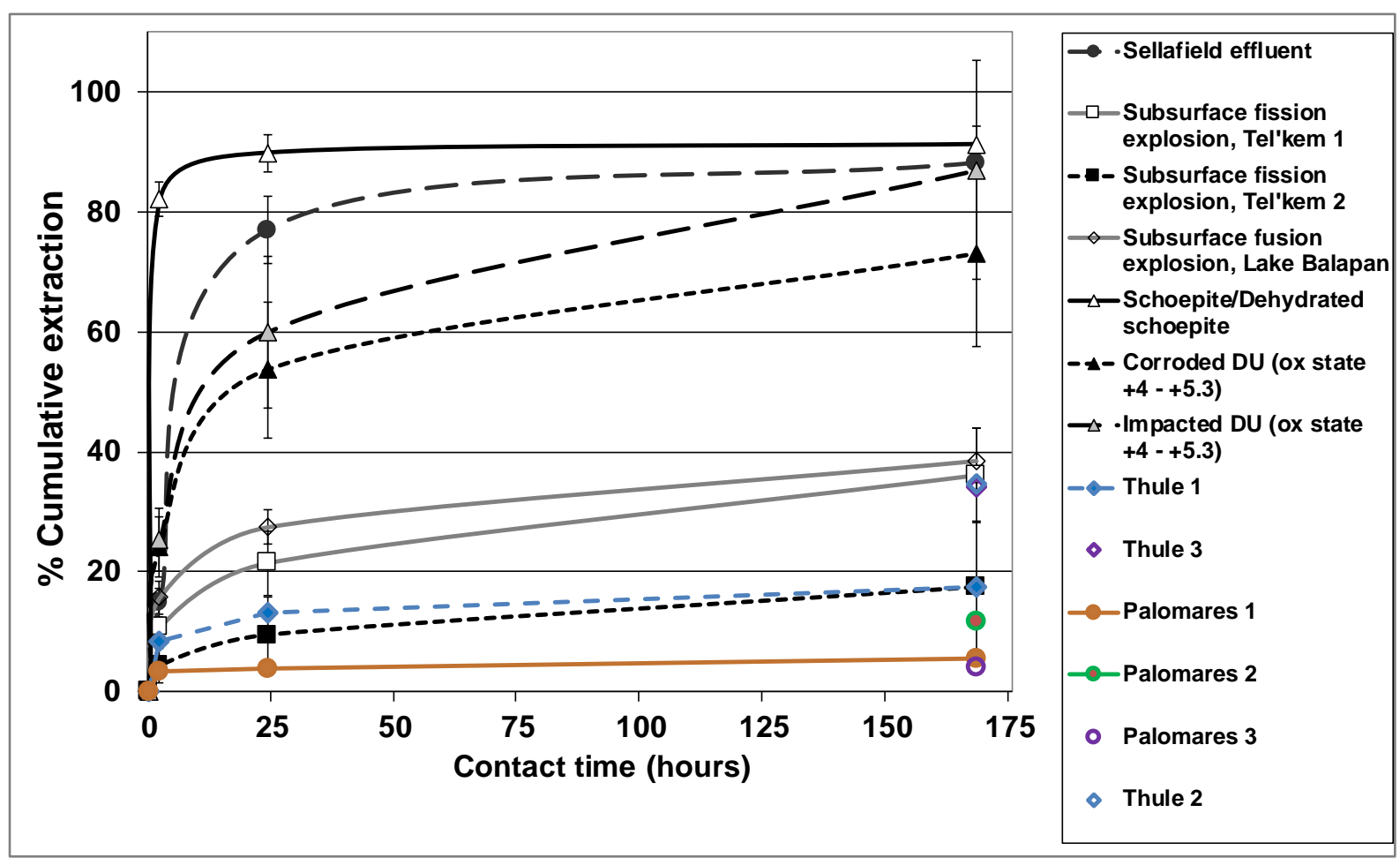

Figure 8. Cumulative extraction (\%) of ${ }^{241} \mathrm{Am}$ from Irish Sea and Semipalatinsk samples, U from DU contaminated samples from Kosovo and Kuwait, and ${ }^{239} \mathrm{Pu}$ Palomares soils and Thule sediments using $0.16 \mathrm{M} \mathrm{HCl}$ as extraction agent at room temperature. Modified from Lind (2006) with additional new data (COMET, 2017).

In contrast to leaching of particle contaminated soil or sediment samples, leaching of individual particles represents important progress in particle science. As illustrated in figure 9, the leaching of radionuclides such as ${ }^{239+240} \mathrm{Pu}$ from an individual particle originating from nuclear tests in Semipalatinsk is a time dependent process, as should be expected. Due to the glassy structure, the relative fraction (\%) leached was very low. Parametrization of the cumulative desorption curve obtained for the Semipalatinsk leaching experiment was performed using the Rosin-Rammler equation. 


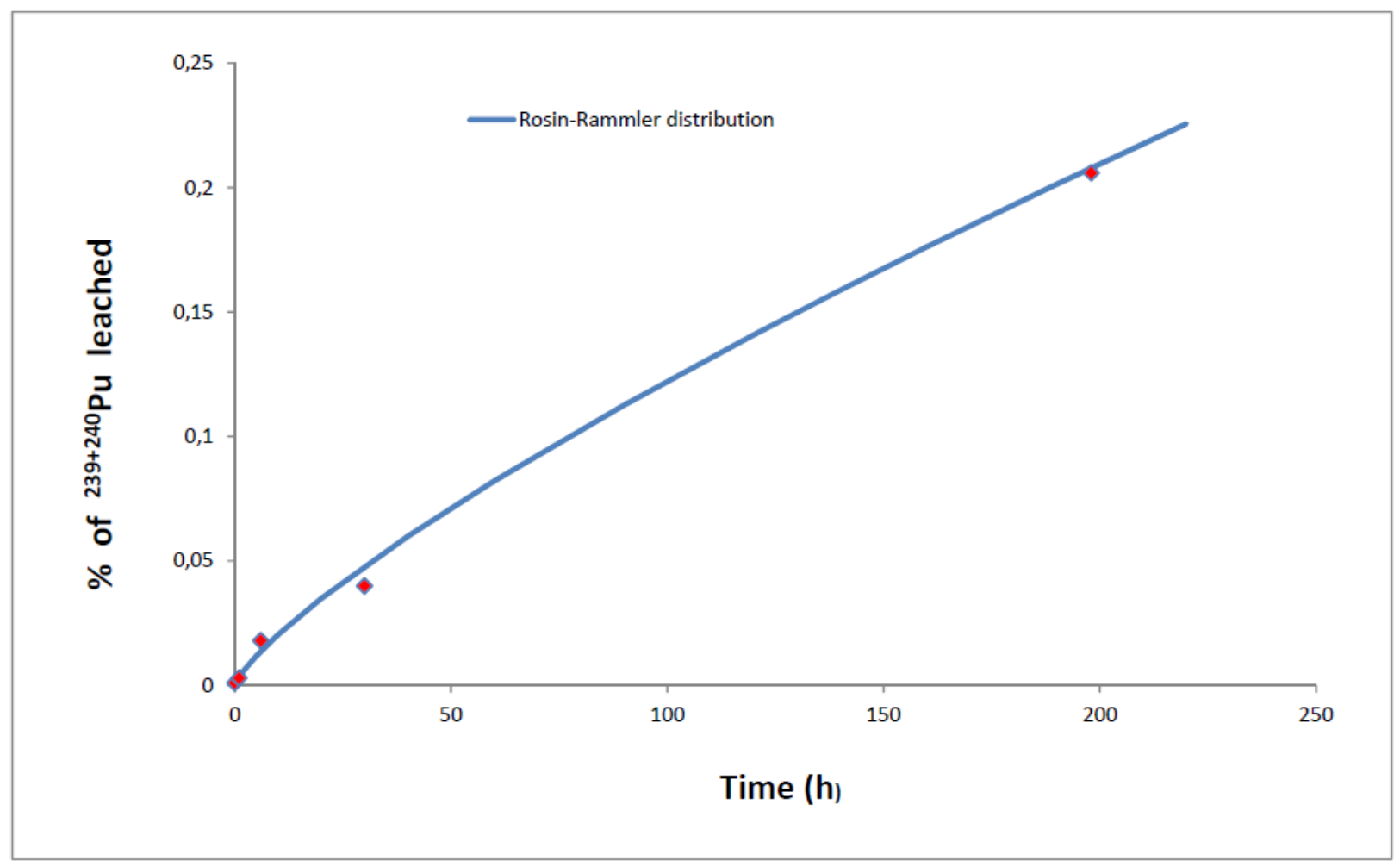

Figure 9. Leaching (\%) of ${ }^{239+240} \mathrm{Pu}$ from a radioactive millimeter sized particle from Ground zero, Semipalatinsk with $0.16 \mathrm{M} \mathrm{HCl}$ as a leaching agent, mimicking the stomach fluids (COMET, 2017).

Within contaminated sites weathering of particles should also result in the decrease of the particle size distributions. Pu containing colloids or pseudocolloids have also been identified in ground waters within Nevada test site (Kersting et al., 1999), and colloidal-facilitated transport of $\mathrm{Pu}$ in ground waters play an important role for transport within test site or at weapon producing sites such as Mayak PA (Novikov et al., 2006). Thus, more attention should be paid to the colloidal behaviour of surface reactive radionuclides within contaminated sites.

As demonstrated for Chernobyl particles, weathering and remobilization of particle associated radionuclides depend on particle properties such as particle size, crystallographic structure and oxidation state as well as physical chemical properties (e.g., pH, TOC) of soils and sediments. Following the explosion, inert $\mathrm{U}-\mathrm{Zr}-\mathrm{O}$ particles were released to the West of the reactor, and the weathering rate was very slow (Fig. 10). Following the subsequent fire, oxidized $\mathrm{UO}_{2}$ fuel (Fig 10a) particles were released to the North and South, and the weathering rate was rapid, as illustrated in figure $10 \mathrm{~b}$. 

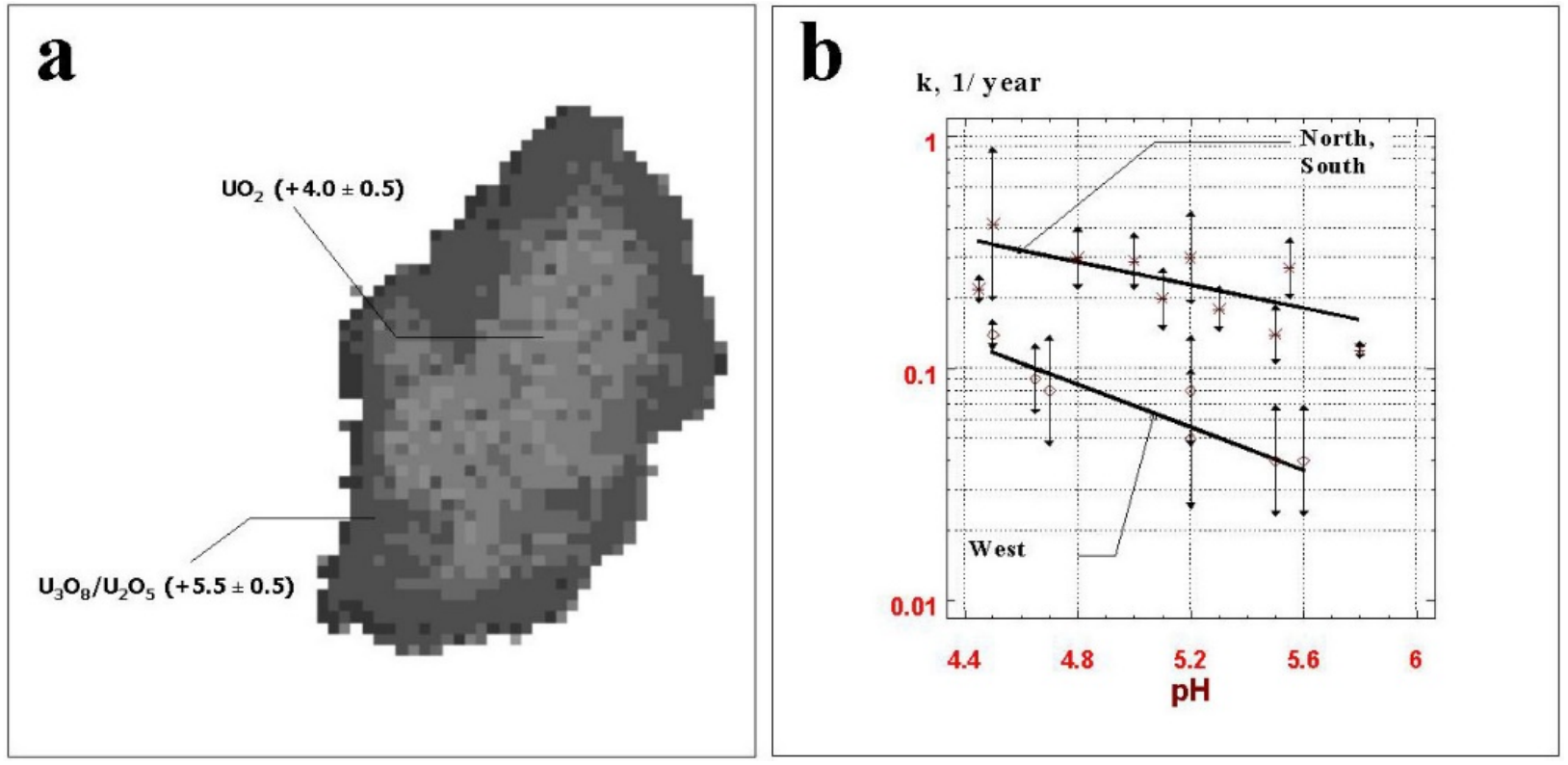

Figure 10. Particles released from the Chernobyl reactor and associated weathering rates. a: Oxidised fuel particle $\left(\mathrm{UO}_{2}\right.$ cores with oxidised $\mathrm{U}_{3} \mathrm{O}_{8}$ and $\mathrm{U}_{2} \mathrm{O}_{5}$ layers) released during the reactor fire obtained from 2-dimentional micro-XANES (Salbu et al., 2000; Salbu et al., 2001a; Salbu et al., 2001c), b: Weathering rates as a function of soil pH for fuel particles released during the explosion (lower) and during the fire (upper) (Kashparov et al., 1999), showing that the weathering rate is more rapid for oxidized $\mathrm{U}$ particles than for inert $\mathrm{U}-\mathrm{Zr}-\mathrm{O}$ particles.

The dissolution process affecting different composition of fuel particles (FP) such as U-Zr-O, $\mathrm{UO}_{2}$ and $\mathrm{UO}_{2+\mathrm{x}}$ particles in surface soils, in the radioactive waste trenches (Red Forest) and in Cooling Pond bottom sediments can be described as a sum of first-order kinetic equations(Kashparov et al., 2012):

$$
\begin{aligned}
& \Delta F P(t)=\sum_{i=1}^{4} \Delta F P_{i}(0) \cdot \exp \left(-\left(k_{i}+\lambda\right) \cdot t\right) \\
& \sum_{i=1}^{4} \Delta F P_{i}(0)=1
\end{aligned}
$$

where $\Delta \mathrm{FP}_{\mathrm{i}}(0)$ is the initial fraction of the fuel particles (part of the activity) of the i-type particles (particle type: i=1 for $\mathbf{U}-\mathbf{Z r}-\mathbf{O}$ particles, $\mathrm{i}=2$ for $\mathbf{U} \mathbf{O}_{2}$ particles, $\mathrm{i}=3$ for $\mathbf{U O}_{2+\mathbf{x}}$ particles and $\mathrm{i}=4$ for condensed component of radionuclides different from FP);

$$
\begin{aligned}
& \mathrm{k}_{\mathrm{i}} \text { - transformation constant of the particles of i-type (year }{ }^{-1} \text { ); } \\
& \lambda \text { - radionuclide decay constant (year }{ }^{-1} \text { ); } \\
& \mathrm{t} \text { - time after the beginning of the dissolution process (years). }
\end{aligned}
$$


Based on experimental results, the half-life of dissolution for $\mathrm{UO}_{2+\mathrm{x}}$ and $\mathrm{UO}_{2}$ particles varied from 14 to $1 \mathrm{yr}$ and from 70 to $7 \mathrm{yr}$, respectively, when the soil acidity (pH) increased from 7 to 4 . The fraction of the very stable particles $\left(\left(\mathrm{U}-\mathrm{Zr}-\mathrm{O}, \mathrm{k}_{1}=0, \Delta \mathrm{FP}_{1}(0)\right)\right.$ was $0.2 \pm 0.1$ for distances up to $10 \mathrm{~km}$ within the western trace and about 0.1 for the southern and northern traces of the Chernobyl fallout. It seems that the inert U-Zr-O fuel particles hardly can be dissolved in soils under natural conditions. Thus, radionuclides associated with these particles will most probable not have any significant influence on the radiological situation in the future, although such entities can be retained by filtering organisms. The presence of such particles should, however, be taken into account when total radionuclide activity concentrations in samples are determined or when remediation technologies are introduced.

Based on experimental work during 2013-2015, the Chernobyl fuel particles dissolution model developed during 1997-2001 could be tested, and the reliability of the predictions related to the dissolution dynamics could be verified by the uptake ${ }^{90} \mathrm{Sr}$, remobilized from particles, into grain (Fig 11). The previous model estimates related to the exchangeable fraction of ${ }^{90} \mathrm{Sr}$ activity in soils with different $\mathrm{pH}$ for the southern trace of fallout coincided with the experimental results obtained in 2013 (COMET, 2017; Otreshko et al., 2014). Recent results on fuel particles dissolution in topsoil and in the Red Forest radioactive waste trench materials showed that the fraction of ${ }^{90} \mathrm{Sr}$ present as mobile species (potential bioavailable form) has reached its maximum values. The dynamics of the ${ }^{90} \mathrm{Sr}$ contamination of vegetation, grain and wood are determined by the kinetics of fuel particle dissolution and by the increase in mobile ${ }^{90} \mathrm{Sr}$-species in the root-layer. Monotonic increase in the concentration ratio (CR) of ${ }^{90} \mathrm{Sr}$ was observed in grains grown in the survey area due to the dissolution of the fuel particles, in accordance with the model predictions (Fig.11.). 


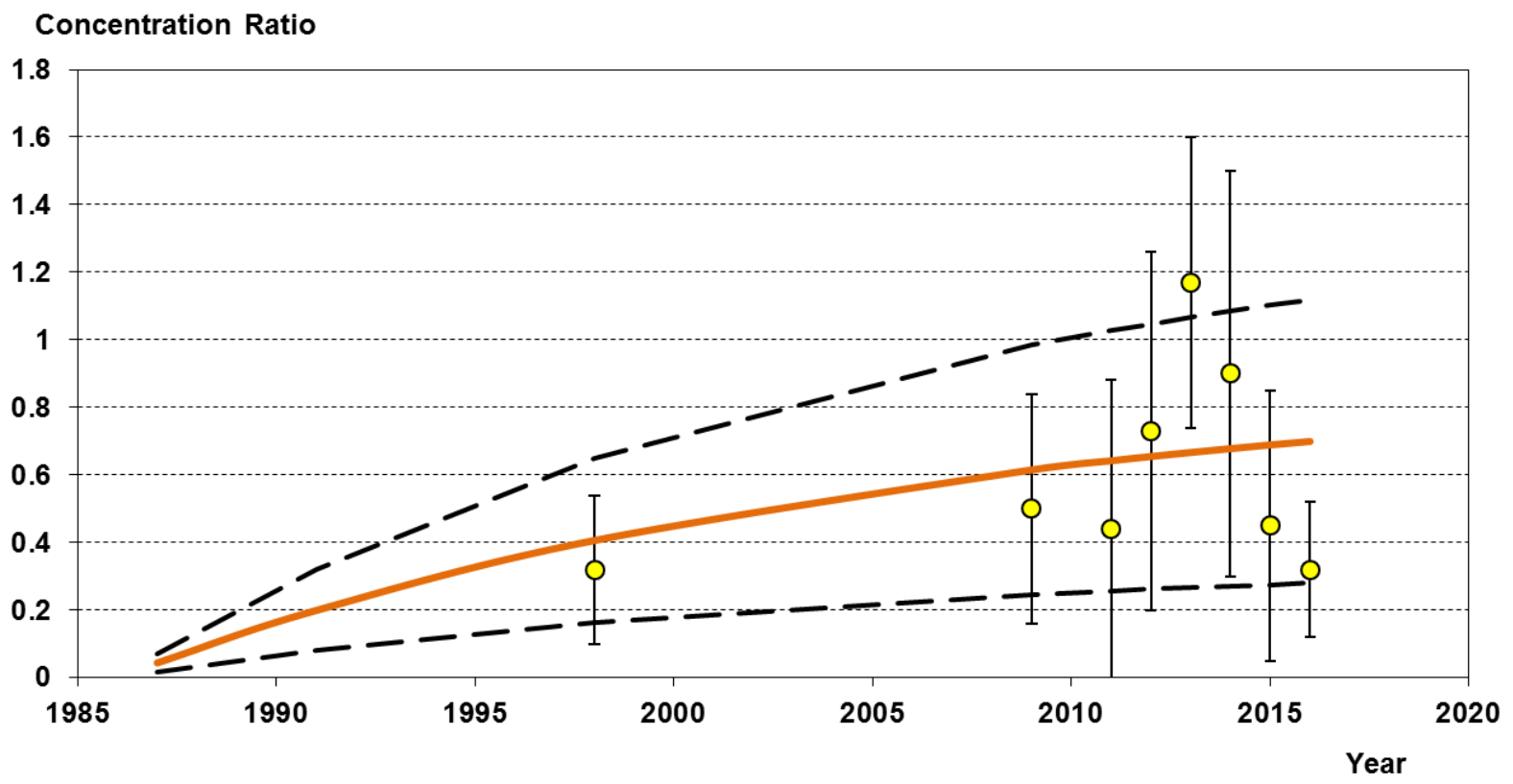

Figure 11. Dynamics of the concentration ratio (CR, Bq/kg grain/Bq/kg soil) of ${ }^{90} \mathrm{Sr}$ (dry weight), and model predictions (solid line, dotted lines: confidence interval with $95 \%$ probability) for soil $\mathrm{pH}=7$ and exchangeable calcium 2-4 meq per 100 g soil. (COMET, 2017).

For fuel particles deposited in the bottom sediments of the Cooling Pond of the ChNPP, more than $98 \%$ of ${ }^{90} \mathrm{Sr},{ }^{137} \mathrm{Cs},{ }^{238} \mathrm{Pu},{ }^{239,240} \mathrm{Pu},{ }^{241} \mathrm{Am}$ are still in non-exchangeable forms. About 70 $80 \%$ of total ${ }^{90} \mathrm{Sr},{ }^{241} \mathrm{Am}$ and plutonium isotopes activity can be located in the matrix of the fuel particles (Protsak and Odintsov, 2014). The low particle weathering rate and remobilization of radionuclides in the sediment in the Cooling Pond are attributed to anoxic conditions and slightly alkaline water due to the presence of a large number of remnant shells of zebra mussels in the sediments. Since 2015, the water level in the pond has decreased $4 \mathrm{~m}$, and the question arise how the presence of air would influence the dissolution of fuel particles in the exposed sediments. Due to the alkaline condition, a sharp increase in the radionuclide mobility in the newly air exposed sediments is not expected (COMET, 2017).

\section{Biological uptake and dosimetry}

Following deposition, radioactive particles can carry substantial amount of radioactivity, and thereby represent point sources of potential long-term environmental and ecological significance. As these materials may include high specific activity radionuclides there is a risk from inhalation, dermal absorption, wound exposure and ingestion of the particles. For filterfeeders (e.g., molluscs), aggregates may be retained by the organism and eventually be ingested 
by man. Furthermore, weathering of radioactive aggregates will increase the mobility and potential for incorporation of particle bound radionuclides into the biosphere.

Observations in the field have also demonstrated that particles are of biological importance. Within the Maralinga and Montebello sites the uptake of Pu is persistent in animals and plants, including particle-influenced uptake in mammals (Johansen et al., 2016; Johansen et al., 2014). For particles released during non-fission tests such as the Taranaki experiments at Maralinga, $\mathrm{Pu}$ associated with the respirable soil fraction ( $<7 \mu$ m diameter) has remained about constant between 1980s and 2012. Similarly, the soil-to-mammal transfer of Pu has remained relatively constant from 1975 to the present (Johansen et al., 2014). These data are consistent with delayed, or gradual, weathering of particles over time (Salbu, 2001), and suggests that the reservoir of particles in the soil at this site will endure for many years into the future as an ongoing source term to the biosphere. At Taranaki, the Pu transfer rate varied within the site; it was low in the centre of the deposition plume where much of the soil Pu was associated with large non-respirable particles and was gradually increasing with distance. While the accumulated Pu was highest in rabbits captured at near source locations, the Pu soil-to-animal uptake ratios (whole-organism concentration ratios, $\mathrm{CR}_{\text {wo-soil }}$ ) were almost three orders of magnitude lower than in rabbits from outside of the plume area where the relative (\%) fraction of respirable Pu particles was higher.

Previous experiments have shown that particles can be retained as a point source in grazing animals (Salbu et al., 1995; Salbu et al., 2004; Zhurba et al., 2009). Oral intake of radioactive particles into organisms of agricultural animals is assumed to be significant, if the animals stay in pastures during or shortly after deposition of radioactive fallout, or are exposed to particles due to soil erosion and resuspension. During the Chernobyl accident, agricultural animals were exposed to fuel particles in pastures through forage, sod and swallowed soil. The behavior of Chernobyl particles in the gastro-intestinal tract of cows after a single oral intake showed that the bioavailability of cesium and strontium isotopes associated with particles was two orders of magnitude lower than the radionuclide species in water-soluble form (Yoschenko et al., 2009). The absorption coefficient of ${ }^{137} \mathrm{Cs}$ from fuel particles in cattle (0.8-1.4 \%) was considerably lower than from ionic species (50-75 \%). The ${ }^{137} \mathrm{Cs}$ concentration in milk peaked 44-68 $\mathrm{h}$ after the administration of particles to the cattle. The radionuclide level decreased exponentially with half-life of 58-69 h. The transport of micrometer-sized U fuel particles in 
the animal gut corresponded with that of the feed, while particles larger than $50 \mu \mathrm{m}$ could be retained in the intestine, acting as a point source.

Aquatic filter feeders are expected to capture and potentially retain radioactive particles, which could then provide localised doses to the contact tissues. Experiments with the blue mussel, Mytilus edulis, exposed to fuel particles originating from the Dounreay nuclear establishment, UK, showed that $37 \%$ of the particles introduced with food were retained for $70 \mathrm{~h}$, and those retained were found on the siphon, gills and stomach. The largest and most radioactive particles induced burn markings (necrosis) in the mantle tissue, increase in DNA damage (Comet tail DNA \%) and increase in micronucleus frequency in the haemolymph collected from the muscle. These responses implied that non-targeted effects of radiation were induced by the radiation from retained particles (Jaeschke et al., 2015).

In the field, Pu particles are taken up by organisms such as mosk oxen from Thule, Greenland, and by hare and snails from Palomares, Spain, as reflected in the presence of Pu particles in the faeces of the animals (COMET, 2017). More than 50 faeces samples from musk oxen grazing at various locations in the Thule area have been analyzed by gamma spectrometry, and ${ }^{241} \mathrm{Am}$ was detected in all samples with activities up to $10 \mathrm{~Bq}$ (equal to about $50 \mathrm{~Bq}{ }^{239} \mathrm{Pu}$ ). In spite of the oral intake, ${ }^{241} \mathrm{Am}$ in all body parts (liver, kidney, bones, lungs, spleen and meat) from a single muskoxen were below the detection limit (2 Bq/kg) (COMET, 2017). Based on snails collected in Palomares, uptake of ${ }^{241} \mathrm{Am}$ was also observed, with levels up to $0.1 \mathrm{~Bq}$ per snail and with concentration ratio (CR) varying up to 3-4 orders of magnitude (COMET, 2017). Micrometer sized -particles of Pu were also found within the faeces, using nano-CT and microXRF techniques. For snails fed with contaminated soils uptake of micrometer sized particles occurred, while most of these particles were excreted. Detectable levels of ${ }^{241} \mathrm{Am}$ were, however, observed in all shells investigated. As illustrated in figure 12, a micrometer sized $\mathrm{Pu}$ particle was embedded in the shell structure of a snail collected in Palomares, and the SEM results were confirmed using nano-CT and micro-XRF (COMET, 2017). 


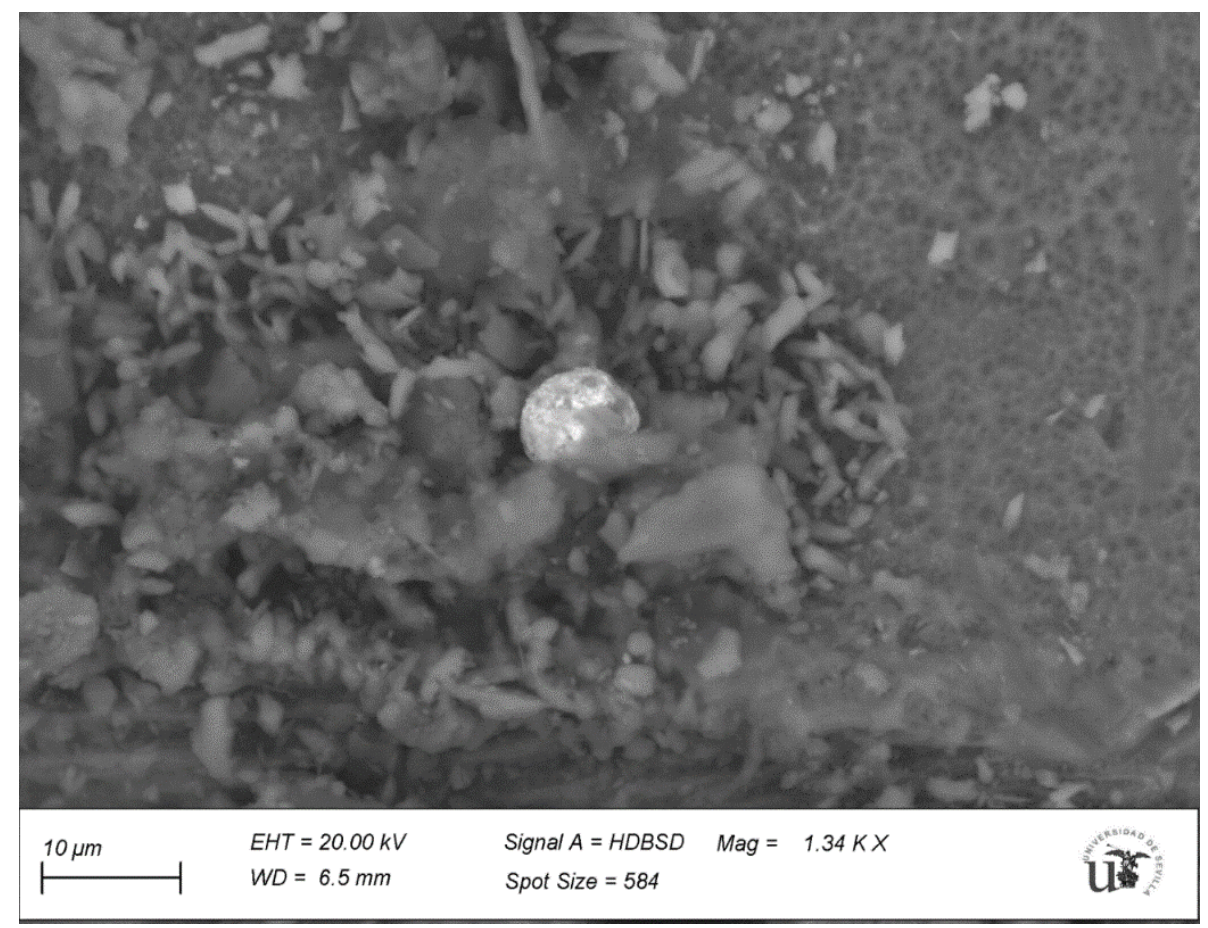

Figure 12. SEM image of a radioactive Pu containing particle embedded in the shell structure of a living snail collected in the Pu contaminated terrestrial area of Palomares, Spain (COMET, 2017).

To estimate the inhalation dose, information on the dispersal composition and the solubility class of inhaled particles is needed. Model experiments with simulated lung fluid have shown that the radioactive Chernobyl fuel traces could be classified as insoluble when inhalation into the human respiratory system was considered (Kashparov et al., 1997). The total absorbed doses of $\alpha$ - and $\beta$-radiation in biological tissue from Chernobyl fuel particles $(0.1-1 \mu \mathrm{m})$ were estimated (Kashparov et al., 1994), taking self-absorption of $\alpha$-radiation by the particle into account. Near the surface of $1 \mu \mathrm{m}$ fuel particles, the total absorbed doses exceeded $10 \mathrm{kGy}$ and decreased to $1 \mathrm{~Gy}$ at a distance of $0.01 \mathrm{~mm}$ after 1 year exposure from May 1, 1986.

Additional dose estimates have been made taking structures and elemental compositions of the particles on a 3-dimensional $\mu \mathrm{m}$ scale into account, using a Monte Carlo code (e.g. MCNP® Los Alamos National Security, LLC). Results quantify the amount of self-shielding (adsorption within the particle) over a range of particle sizes and compositions, as well as the amount of energy that escapes the particle and is absorbed by surrounding tissue when the particle is assumed to be lodged within an organism. The particle structure also has implications for radiological exposure. Model calculations provide estimates of the relative fraction (\%) of alpha emission energy that is deposited within a Pu-containing particle (self-shielding) versus 
that deposited in surrounding tissue (Fig. 13). The relative fraction (\%) deposited in tissue was highest for smaller particles and equivalence in particles with $\sim 3 \mu \mathrm{m}$ diameter. The model results suggest that when particles are of respirable sizes (e.g. $<7 \mu \mathrm{m}$ ), or when the Pu content exists on exterior surfaces, that an internalised particle may produce relatively intense dose rates to adjacent tissues, as well as acting as an ongoing source of radionuclides that can be available for absorption into the body (COMET, 2017).
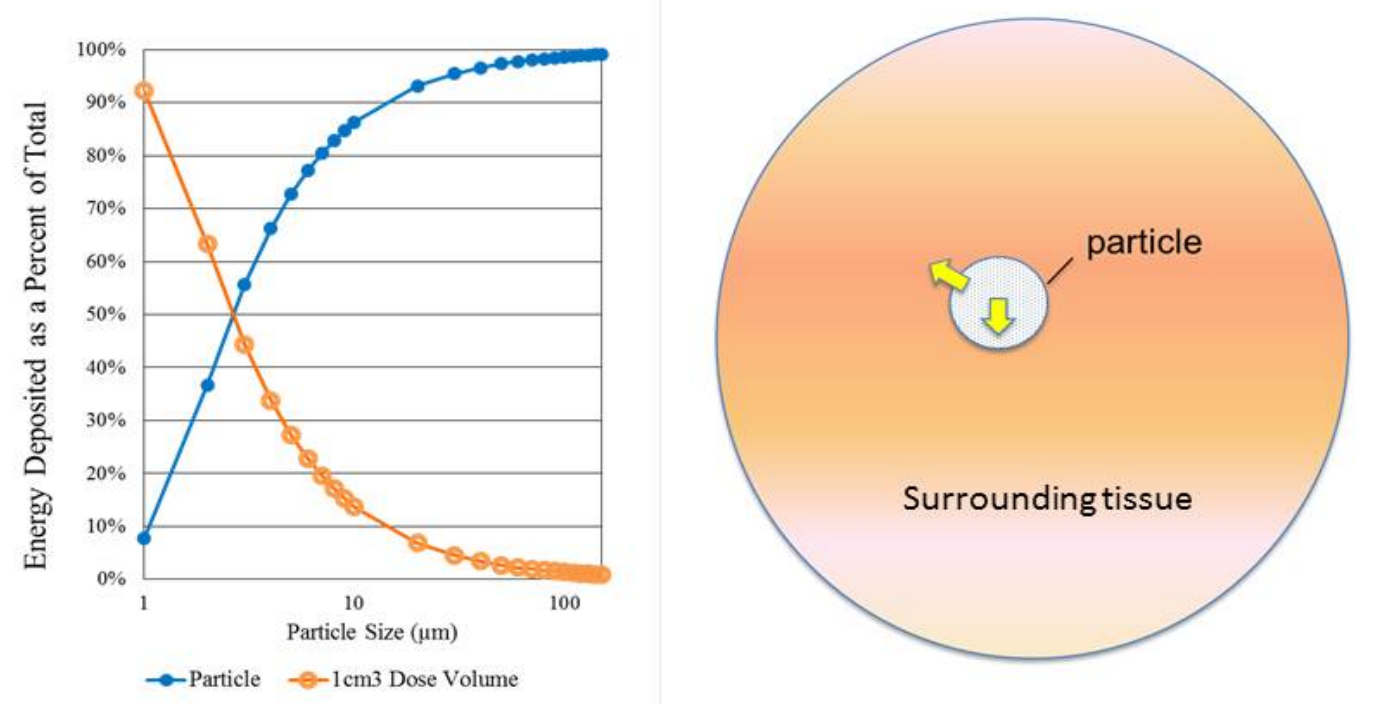

Figure 13. Model data indicating, for a range of particle sizes, the relative fraction (\%) of alpha emission energy that is deposited within a Pu-containing particle (blue symbols) versus that deposited in surrounding tissue (orange symbols). The Pu was assumed to be homogenously distributed within a spherical particle, adapted from Caffrey et al. (2016).

\section{Conclusions - challenges associated with particles in the environment}

To assess environmental impact and risks associated with radioactive particles deposited in different ecosystems, key challenges include the linking of particle characteristics to specific sources, to ecosystem transfer and to uptake and retention in exposed organisms of relevance for dose estimates .

It is well established that a major fraction of refractory radionuclides such as uranium (U) and plutonium $(\mathrm{Pu})$ released to the environment from the nuclear weapon and fuel cycles is present as particles ranging from submicrons to fragments. Such particles can carry a substantial amount of radioactivity (e.g., fission and activation products, transuranics) and associated metals, and can act as point sources. Furthermore, U particles (progenies, metals) are present 
at NORM sites (IAEA, 2011). Research indicates that particle characteristics such as composition, atom and element ratios depend on the emitting source, while particle characteristics essential for ecosystem transfer and biological uptake such as particle size distribution, crystallographic structures, oxidation states and solubility depend mostly on the release conditions. To obtain information on particle characteristics, advanced techniques and equipment are essential. A key challenge is to link particle characteristics to specific nuclear and radiological sources and to specific release scenarios. This require access to contaminated sites, as well as access to advanced technology such as synchrotron radiation facilities, preferentially at nano-or microbeam lines. Although the presence of radioactive particles is well established, a key challenge is to estimate the frequency of the phenomenon. Proper particle characterization require comprehensive work on relatively few isolated particles, while techniques available to estimate density of nanometer sized particles are limited.

Following deposition, radioactive particles can be retained in soils and sediments. Thus, the ecosystem transfer of particle associated radionuclides will be delayed compared to mobile species. Due to particle weathering processes, particle associated radionuclides are remobilized and contaminated soils and sediments can act as diffuse sources of radioactivity in the future. A challenge is therefore to link particle characteristics to ecosystem behavior, and to identify how environmental factors such as $\mathrm{pH}$, redox, TOC and the presence of microbial activities can influence particle weathering processes. Thus, information is needed not only on transformation processes and interactions, but also on the kinetics of the processes and to utilize this information to replace thermodynamic constants (Kd, CR, TF, TC) with time functions.

The present work has demonstrated that particle weathering occurs, and that particle associated radionuclides such as ${ }^{90} \mathrm{Sr}$ can be remobilized. The work has also demonstrated that radioactive particles are of biological relevance. Particles can be inhaled or ingested, and can be retained within organisms in the field such as snails, acting as point sources. The bioavailability and uptake of particle-bound radionuclides compared with those existing as ions or simple molecules has so far largely been ignored when impact and risk are assessed. As a result, there is a high degree of scientific uncertainty about the long-term ecological consequences and risk to human health from radioactive particles present in the environment (IAEA, 2011). As particles and their associated dose will be inhomogeneously distributed within organisms, a key challenge is also to improve microdosimetry models used for characterizing uneven distribution of dose from small high specific activity particles, being inadequate today. 
Finally, the overall challenge is related to conceptual or structural uncertainties in environmental impact and risk assessments associated with radioactive particle contaminated areas, where important aspects are ignored, such as:

- Source term characteristics, ignoring particle characteristics with implications for transport, deposition and ecosystem transfer.

- Constant ecosystem transfer parameters, ignoring particle weathering and dynamics, changes in pathways and particle retention in organisms.

- Dose estimate, ignoring that point sources and the associated dose will be unevenly distributed

Although recent projects such as COMET and RATE and the IAEA CRP have contributed with important knowledge on particle characteristics, weathering and leaching being essential for ecosystem transfer, as well as on biological relevance of particles, further research is clearly needed to address the challenges identified. As particle releases were seen following many kinds of historic nuclear events, particle releases should also be expected from events occurring in the future. Therefore, existing radiological accidental and release sites should be utilized to improve the knowledge needed to link particle characteristics to sources, to transfer and to biological effects on which sound environmental assessments can be made.

\section{Acknowledgement}

This work was supported by the EC-funded COMET (Contract Number: Fission-2012-3.4.1604794) - RATE (Grant agreement number: 604974) projects. Part of the work is also supported by the Research Council of Norway through its Centres of Excellence funding scheme, project number 223268/F50. The authors are indebted to close collaborators at the author institutions, as well as to professor L.K. Fifield and Dr. Steve Tims, National University Canberra for providing AMS Pu data for Palomares and Thule sediment and leachate samples. The authors are also indebted to Jakub Jaroszewicz, Warsaw University of Technology, Poland, for nano-tomography analyses.

\section{References}

Abe, Y., Iizawa, Y., Terada, Y., Adachi, K., Igarashi, Y., Nakai, I., 2014. Detection of Uranium and Chemical State Analysis of Individual Radioactive Microparticles Emitted from the Fukushirna Nuclear Accident Using Multiple Synchrotron Radiation X-ray Analyses. Analytical Chemistry 86, 8521-8525. 
Alsecz, A., Osan, J., Kurunczi, S., Alfoldy, B., Varhegyi, A., Torok, S., 2007. Analytical performance of different X-ray spectroscopic techniques for the environmental monitoring of the recultivated uranium mine site. Spectrochimica Acta Part B-Atomic Spectroscopy 62, 769-776.

AMAP, 1997. Arctic pollution issues: Radioactive contamination. Norwegian Radiation Protetion Authority, Østerås, pp. 1-160.

Beresford, N.A., Fesenko, S., Konoplev, A., Skuterud, L., Smith, J.T., Voigt, G., 2016. Thirty years after the Chernobyl accident: What lessons have we learnt? Journal of Environmental Radioactivity 157, 77-89.

Boehnke, A., Treutler, H.C., Freyer, K., Schubert, M., Holger, W., 2005. Localisation and identification of radioactive particles in solid samples by means of a nuclear track technique. Radiation Measurements 40, 650-653.

Burns, P.A., Cooper, M.B., Lokan, K.H., Wilks, M.J., Williams, G.A., 1995. Characteristics of Plutonium and Americium Contamination at the Former Uk Atomic Weapons Test Ranges at Maralinga and Emu. Applied Radiation and Isotopes 46, 1099-1107.

Caffrey, E.A., Johansen, M.P., Higley, K.A., 2016. Voxel modeling of rabbits for use in radiological dose rate calculations. Journal of Environmental Radioactivity 151, Part 2, 480-486.

Child, D.P., Hotchkis, M.A.C., 2013. Plutonium and uranium contamination in soils from former nuclear weapon test sites in Australia. Nuclear Instruments and Methods in Physics Research Section B: Beam Interactions with Materials and Atoms 294, 642-646.

COMET, 2017. Final Report of the European Comission funded COMET-RATE Project, (Contract Number: Fission-2012-3.4.1604794). Deliverable 3.7.

Conradson, S.D., 2000. XAFS - A Technique to Probe Local Structure. Los Alamos Science 26, 422435.

Conway, M., Vintro, L.L., Mitchell, P.I., Garcia-Tenorio, R., Jimenez-Ramos, M.C., Burkitbayev, M., Priest, N.D., 2009. In-vitro analysis of the dissolution kinetics and systemic availability of plutonium ingested in the form of 'hot' particles from the Semipalatinsk NTS. Applied Radiation and Isotopes 67, 884-888.

Cooke, A.I., Green, N., Rimmer, D.L., Weekes, T.E.C., Wilkins, B.T., 1995. Development of an invitro method to assess the availability of soil-associated radionuclides for uptake by ruminants. Journal of Environmental Radioactivity 28, 191-207.

Cresswell, A.J., Sanderson, D.C.W., 2012. Evaluating airborne and ground based gamma spectrometry methods for detecting particulate radioactivity in the environment: A case study of Irish Sea beaches. Science of the Total Environment 437, 285-296.

Crocker, G.R., Oconnor, J.D., Freiling, E.C., 1966. Physical and Radiochemical Properties of Fallout Particles. Health Physics 12, 1099.

Dahlgaard, H., Eriksson, M., Ilus, E., Ryan, T., McMahon, C.A., Nielsen, S.P., 2001. Plutonium in the marine environment at Thule, NW-Greenland after a nuclear weapons accident, in: Kudo, A. (Ed.), Plutonium in the environment. Elsevier, Oxford, pp. 15-30.

Danesi, P.R., Moreno, J., Makarewicz, M., Radecki, Z., 2002. Residual radioactivity in the terrestrial environment of the Mururoa and Fangataufa Atolls nuclear weapon test sites. Journal of Radioanalytical and Nuclear Chemistry 253, 53-65.

Devell, L., Tovedal, H., Bergstrom, U., Appelgren, A., Chyssler, J., Andersson, L., 1986. Initial Observations of Fallout from the Reactor Accident at Chernobyl. Nature 321, 192-193.

Eriksson, M., 2002. On weapons plutonium in the Arctic environment (Thule, Greenland), PhD thesis. Risø National Laboratory, pp. 1-146.

Eriksson, M., Lindahl, P., Roos, P., Dahlgaard, H., Holm, E., 2008. U, Pu, and Am nuclear signatures of the Thule hydrogen bomb debris. Environmental Science \& Technology 42, 4717-4722.

Eriksson, M., Osan, J., Jernstrom, J., Wegrzynek, D., Simon, R., Chinea-Cano, E., Markowicz, A., Bamford, S., Tamborini, G., Torok, S., Falkenberg, G., Alsecz, A., Dahlgaard, H., Wobrauschek, P., Streli, C., Zoeger, N., Betti, M., 2005. Source term identification of environmental radioactive $\mathrm{Pu} / \mathrm{U}$ particles by their characterization with non-destructive spectrochemical analytical techniques. Spectrochimica acta, Part B: Atomic spectroscopy 60, 455-469.

Hamilton, T.F., Jernstroem, J., Martinelli, R.E., Kehl, S.R., Eriksson, M., Williams, R.W., Bielewski, M., Rivers, A.N., Brown, T.A., Tumey, S.J., Betti, M., 2009. Frequency distribution, isotopic 
composition and physical characterization of plutonium-bearing particles from the Fig-Quince zone on Runit Island, Enewetak Atoll. Journal of Radioanalytical and Nuclear Chemistry 282, 1019-1026.

IAEA, 1998. Radiological Conditions at the Semipalatinsk Test Site, Kazakhstan: Preliminary Assessment and Recommendations for Further Studies. International Atomic Energy Agency, Vienna, pp. 1-43.

IAEA, C.R.P., 2011. Radioactive Particles in the Environment: Sources, particle characteristics and analytical techniques, IAEA-TECDOC. IAEA, Vienna, p. 90.

Ikeda-Ohno, A., Shahin, L.M., Howard, D.L., Collins, R.N., Payne, T.E., Johansen, M.P., 2016. Fate of Plutonium at a Former Nuclear Testing Site in Australia. Environ. Sci. Technol. 50, 9098-9104.

Jaeschke, B.C., Lind, O.C., Bradshaw, C., Salbu, B., 2015. Retention of radioactive particles and associated effects in the filter-feeding marine mollusc Mytilus edulis. Science of The Total Environment 502, 1-7.

Johansen, M.P., Child, D.P., Caffrey, E.A., Davis, E., Harrison, J.J., Hotchkis, M.A.C., Payne, T.E., Ikeda-Ohno, A., Thiruvoth, S., Twining, J.R., Beresford, N.A., 2016. Accumulation of plutonium in mammalian wildlife tissues following dispersal by accidental-release tests. Journal of Environmental Radioactivity 151, Part 2, 387-394.

Johansen, M.P., Child, D.P., Davis, E., Doering, C., Harrison, J.J., Hotchkis, M.A., Payne, T.E., Thiruvoth, S., Twining, J.R., Wood, M.D., 2014. Plutonium in wildlife and soils at the Maralinga legacy site: persistence over decadal time scales. J. Environ. Radioact. 131, 72-80.

Kashparov, V., Yoschenko, V., Levchuk, S., Bugai, D., Van Meir, N., Simonucci, C., Martin-Garin, A., 2012. Radionuclide migration in the experimental polygon of the Red Forest waste site in the Chernobyl zone - Part 1: Characterization of the waste trench, fuel particle transformation processes in soils, biogenic fluxes and effects on biota. Applied Geochemistry 27, 1348-1358.

Kashparov, V.A., 2003. Hot particles at Chernobyl. Environmental Science and Pollution Research, 2130.

Kashparov, V.A., Ahamdach, N., Zvarich, S.I., Yoschenko, V.I., Maloshtan, I.M., Dewiere, L., 2004. Kinetics of dissolution of Chernobyl fuel particles in soil in natural conditions. Journal of Environmental Radioactivity 72, 335-353.

Kashparov, V.A., Ioshchenko, V.I., Zvarich, S.I., Protsak, V.P., Pazukhin, E.M., 1997. Determination of solubility class of Chernobyl radioactive aerosols at inhalation 18. Radiochemistry 39, 74-76.

Kashparov, V.A., Lundin, S.M., Zvarych, S.I., Yoshchenko, V.I., Levchuk, S.E., Khomutinin, Y.V., Maloshtan, I.M., Protsak, V.P., 2003. Territory contamination with the radionuclides representing the fuel component of Chernobyl fallout. Science of the Total Environment 317, 105-119.

Kashparov, V.A., Oughton, D.H., Protsak, V.P., Zvarisch, S.I., Levchuk, S.E., 1999. Kinetics of fuel particle weathering and 90Sr mobility in the Chernobyl 30 km exclusion zone. Health Physics 76, 251259.

Kashparov, V.A., Protsak, V.P., Ahamdach, N., Stammose, D., Peres, J.M., Yoshchenko, V.I., Zvarich, S.I., 2000. Dissolution kinetics of particles of irradiated Chernobyl nuclear fuel: influence of $\mathrm{pH}$ and oxidation state on the release of radionuclides in the contaminated soil of Chernobyl. Journal of Nuclear Materials 279, 225-233.

Kennedy, V.H., Sanchez, A.L., Oughton, D.H., Rowland, A.P., 1997. Use of single and sequential chemical extractants to assess radionuclide and heavy metal availability from soils for root uptake. Analyst 122, R89-R100.

Kersting, A.B., Efurd, D.W., Finnegan, D.L., Rokop, D.J., Smith, D.K., Thompson, J.L., 1999. Migration of plutonium in ground water at the Nevada Test Site. Nature 397, 56-59.

Kuriny, V.D., Ivanov, Y.A., Kashparov, V.A., Loshchilov, N.A., Protsak, V.P., Yudin, E.B., Zhurba, M.A., Parshakov, A.E., 1993. Particle-Associated Chernobyl Fallout in the Local and Intermediate Zones. Annals of Nuclear Energy 20, 415-420.

Landa, E.R., Stieff, L.R., Germani, M.S., Tanner, A.B., Evans, J.R., 1994. Intense Alpha-Particle Emitting Crystallites in Uranium Mill Wastes. Nuclear Geophysics 8, 443-454.

Lind, O.C., 2006. Characterisation of radioactive particles in the environment using advanced techniques, PhD thesis. Norwegian University of Life Sciences, Ås, pp. 1-191.

Lind, O.C., De Nolf, W., Janssens, K., Salbu, B., 2013a. Micro-analytical characterisation of radioactive heterogeneities in samples from Central Asian TENORM sites. Journal of Environmental Radioactivity 123, 63-70. 
Lind, O.C., De Nolf, W., Salbu, B., Janssens, K., 2011. Microanalytical characterisation of radioactive TENORM particles, in: Barescut, J.C. (Ed.), International Conference on Radioecology \& Environmental Radioactivity. Norwegian Radiation Protection Authority, Østerås. ISBN 978-8290362-30-5.

Lind, O.C., Salbu, B., De Nolf, W., Jaroszewicz, J., Janssens, K., Falkenberg, G., 2008. Reexamination of $\mathrm{U}$ and $\mathrm{Pu}$ in particles from Thule and Palomares by micro-XRD, HASYLAB annual report. HASYLAB, Hamburg.

http://hasyweb.desy.de/science/annual_reports/2007_report/part1/contrib/45/22056.pdf

Lind, O.C., Salbu, B., Janssens, K., Proost, K., Dahlgaard, H., 2005. Characterization of uranium and plutonium containing particles originating from the nuclear weapons accident in Thule, Greenland, 1968. Journal of Environmental Radioactivity 81, 21-32.

Lind, O.C., Salbu, B., Janssens, K., Proost, K., Garcia-Leon, M., Garcia-Tenorio, R., 2007. Characterization of U/Pu particles originating from the nuclear weapon accidents at Palomares, Spain, 1966 and Thule, Greenland, 1968. Science of the Total Environment 376, 294-305.

Lind, O.C., Salbu, B., Skipperud, L., Janssens, K., Jaroszewicz, J., De Nolf, W., 2009. Solid state speciation and potential bioavailability of depleted uranium particles from Kosovo and Kuwait. Journal of Environmental Radioactivity 100, 301-307.

Lind, O.C., Stegnar, P., Tolongutov, B., Rosseland, B.O., Stromman, G., Uralbekov, B., Usubalieva, A., Solomatina, A., Gwynn, J.P., Lespukh, E., Salbu, B., 2013b. Environmental impact assessment of radionuclide and metal contamination at the former U site at Kadji Sai, Kyrgyzstan. Journal of Environmental Radioactivity 123, 37-49.

Lopez, J.G., Jimenez-Ramos, M.C., Garcia-Leon, M., Garcia-Tenorio, R., 2007. Characterisation of hot particles remaining in soils from Palomares (Spain) using a nuclear microprobe. Nuclear Instruments \& Methods in Physics Research Section B-Beam Interactions with Materials and Atoms 260, 343-348. Lucey, J.A., Gouzy, A., Boust, D., Vintro, L.L., Bowden, L., Finegan, P.P., Kershaw, P.J., Mitchell, P.I., 2004. Geochemical fractionation of plutonium in anoxic Irish Sea sediments using an optimised sequential extraction protocol. Applied Radiation and Isotopes 60, 379-385.

Mamuro, T., Fujita, A., Matsunami, T., 1965. Microscope Examination of Highly Radioactive Fallout Particles from First Chinese Nuclear Test Explosion. Health Physics 11, 1097-1101.

Mamuro, T., Fujita, A., Yoshikawa, K., Matsunami, T., 1962. Microscopic Examination of Highly Radioactive Fall-Out Particles. Nature 196, 529.

Mamuro, T., Yoshikaw, K., Matsunami, T., Fujita, A., 1966. Radionuclide Fractionation in Debris from A Land Surface Burst. Health Physics 12, 757-763.

MARTAC, 2003. Rehabilitation of the Former Nuclear Test Sites at Emu and Maralinga (Australia) 2003; Report by the Maralinga Rehabilitation technical Advisory Committee. Maralinga Rehabilitation technical Advisory Committee, Canberra, Australia.

Miyamoto, Y., Yasuda, K., Magara, M., 2014. Size distribution of radioactive particles collected at Tokai, Japan 6 days after the nuclear accident. Journal of Environmental Radioactivity 132, 1-7.

Napoles, H.J., Vintro, L.L., Mitchell, P.I., Omarova, A., Burkitbayev, M., Priest, N.D., Artemyev, O., Lukashenko, S., 2004. Source-term characterisation and solid speciation of plutonium at the Semipalatinsk NTS, Kazakhstan. Applied Radiation and Isotopes 61, 325-331.

Novikov, A.P., Kalmykov, S.N., Utsunomiya, S., Ewing, R.C., Horreard, F., Merkulov, A., Clark, S.B., Tkachev, V.V., Myasoedov, B.F., 2006. Colloid transport of plutonium in the far-field of the Mayak Production Association, Russia. Science 314, 638-641.

Otreshko, L.M., Levchuk, S.E., Yoshchenko, V.I., 2014. Activity concentration of 90Sr in grain on fuel traces of Chernobyl radioactive fallout. Nuclear Physics and Atomic Energy 15, 171-177.

Popic, J.M., Salbu, B., Strand, T., Skipperud, L., 2011. Assessment of radionuclide and metal contamination in a thorium rich area in Norway. Journal of Environmental Monitoring 13, 1730-1738. Ranebo, Y., Eriksson, M., Tamborini, G., Niagolova, N., Bildstein, O., Betti, M., 2007. The use of SIMS and SEM for the characterization of individual particles with a matrix originating from a nuclear weapon. Microscopy and Microanalysis 13, 179-190.

Salbu, B., 1988. Radionuclides associated with colloids and particles in rainwaters, Oslo, Norway, in: von Philipsborn, H., Steinh,,user, F. (Eds.), Hot particles from the Chernobyl Fallout. Bergbau - und Industrimuseum, Theuern, pp. 83-84. 
Salbu, B., 2000. Speciation of Radionuclides in the Environment, in: R.A.Meyers (Ed.), Encyclopedia of Analytical Chemistry. John Wiley \& Sons Ltd, Chichester, pp. 12993-13016.

Salbu, B., 2001. Actinides associated with particles, in: Kudo, A. (Ed.), Plutonium in the Environment; Proceedings of the Second International Symposium. Elsevier, pp. 121-138.

Salbu, B., Janssens, K., Krekling, T., Simionovici, A., Drakopoulos, M., Raven, C., Snigireva, I., Snigirev, A., Lind, O.C., Oughton, D.H., Adams, F., Kashparov, V.A., 2000. $\mu$-X-ray Absorption Tomography and $\mu$-XANES for Characterisation of Fuel Particles, in: Cornuejols, D., Admans, G. (Eds.), ESRF Highlights 1999. European Synchrotron Radiation Facility, pp. 24-25.

Salbu, B., Janssens, K., Lind, O.C., Proost, K., Gijsels, L., Danesi, P.R., 2005. Oxidation states of uranium in depleted uranium particles from Kuwait. Journal of Environmental Radioactivity 78, 125135.

Salbu, B., Krekling, T., Hove, K., Oughton, D.H., Kashparov, V.A., Astasheva, N.P., 1995. Biological relevance of hot particles ingested by domestic sheep, International Symposium on Environmental Impact of Radioactive Releases. IAEA, Vienna, pp. 312-313.

Salbu, B., Krekling, T., Lind, O.C., Oughton, D.H., Drakopoulos, M., Simionovici, A., Snigireva, I., Snigirev, A., Weitkamp, T., Adams, F., Janssens, K., Kashparov, V., 2001a. High energy X-ray microscopy for characterisation of fuel particles. High energy X-ray microscopy for characterisation of fuel particles, 1249-1252.

Salbu, B., Krekling, T., Lind, O.C., Oughton, D.H., Drakopoulos, M., Simionovici, A., Snigireva, I., Snigirev, A., Weitkamp, T., Adams, F., Janssens, K., Kashparov, V.A., 2001b. High energy X-ray microscopy for characterisation of fuel particles. Nuclear Instruments \& Methods in Physics Research Section A-Accelerators Spectrometers Detectors and Associated Equipment 467, 1249-1252.

Salbu, B., Krekling, T., Oughton, D.H., Ostby, G., Kashparov, V.A., Brand, T.L., Day, J.P., 1994. Hot Particles in Accidental Releases from Chernobyl and Windscale Nuclear Installations. Analyst 119, 125-130.

Salbu, B., Lind, O.C., 2016. Radioactive Particles Released to the Environment from the Fukushima Reactors-Confirmation Is Still Needed. Integr. Environ. Assess. Manag. 12, 687-689.

Salbu, B., Lind, O.C., Borretzen, P., Oughton, D., Brechignac, F., Howard, B., 2001c. Advanced speciation techniques for radionuclides associated with colloids and particles, Radioactive pollutants Impact on the environment. EDP Sciences, Les Ulis Cedex A, pp. 243-260.

Salbu, B., Lind, O.C., Skipperud, L., 2004. Radionuclide speciation and its relevance in environmental impact assessments. Journal of Environmental Radioactivity 74, 233-242.

Sandalls, F.J., Segal, M.G., Victorova, N., 1993. Hot particles from Chernobyl - a review. Journal of Environmental Radioactivity 18, 5-22.

Sdraulig, S., Franich, R., Tinker, R.A., Solomon, S., O'Brien, R., Johnston, P.N., 2008. In vitro dissolution studies of uranium bearing material in simulated lung fluid. Journal of Environmental Radioactivity 99, 527-538.

Selchau-Hansen, K., Ghose, R., Freyer, K., Treutler, C., Enge, W., 1999. Hot particles in industrial waste and mining tailings. Radiation Measurements 31, 451-454.

Skipperud, L., Salbu, B., 2015. Sequential extraction as a tool for mobility studies of radionuclides and metals in soils and sediments. Radiochimica Acta 103, 187-197.

Smith, J.N., Ellis, K.M., Polyak, L., Ivanov, G., Forman, S.L., Moran, S.B., 2000. 239,240 Pu transport into the Arctic Ocean from underwater nuclear tests in Chernaya Bay, Novaya Zemlya 61. Continental Shelf Research 20, 255-279.

Solodukhin, V.P., 2005. Nuclear-physical methods in macro- and microanalytical investigations of contamination with radionuclides at Semipalatinsk Nuclear Test Site. Journal of Radioanalytical and Nuclear Chemistry 264, 457-462.

UNSCEAR, 2000. Sources and effects of ionizing radiation. United Nations, New York, p. 1.

Wendel, C.C., Fifield, L.K., Oughton, D.H., Lind, O.C., Skipperud, L., Bartnicki, J., Tims, S.G., Høibråten, S., Salbu, B., 2013. Long-range tropospheric transport of uranium and plutonium weapons fallout from Semipalatinsk nuclear test site to Norway. Environment International 59, 92-102.

Yoschenko, V., Kashparov, V., Lazarev, M., 2009. Hot particles behavior in cows after peroral intake, in: Oughton, D.H., Kashparov, V. (Eds.), Radioactive Particles in the Environment, pp. 259-267. 
Zhurba, M., Kashparov, V., Ahamdach, N., Salbu, B., Yoschenko, V., Levchuk, S., 2009. The "hot particles" data base, in: Oughton, D.H., Kashparov, V. (Eds.), Radioactive Particles in the Environment, pp. 187-195. 